\title{
Looking for prosocial genes: iTRAQ analysis of proteins involved in MDMA-induced sociability in mice
}

Konstantin Kuteykin-Teplyakov ${ }^{\#}$ and Rafael Maldonado

Laboratory of Neuropharmacology, Universitat Pompeu Fabra, Barcelona, Spain.

Running short title: iTRAQ analysis of MDMA-induced sociability.

Address correspondence and reprint requests to: Laboratory of Neuropharmacology,

Department of Natural Sciences and Health, Universitat Pompeu Fabra, Carrer Dr. Aiguader 88, Barcelona, 08003, Spain. Tel.: +34 93 3160824, fax: +34 933160901.

\# Corresponding author for editorial purposes: konstantin.kuteykin@upf.edu, Tel. +34 693038816. 


\begin{abstract}
Social behavior plays a fundamental role in life of many animal species, allowing the interaction between individuals and sharing of experiences, needs, and goals across them. In humans, some neuropsychiatric diseases, including anxiety, posttraumatic stress disorder and autism spectrum disorders, are often characterized by impaired sociability. Here we report that N-Methyl-3,4methylenedioxyamphetamine (MDMA, "Ecstasy") at low dose (3 mg/kg) has differential effects on mouse social behavior. In some animals, MDMA promotes sociability without hyperlocomotion, whereas in other mice it elevates locomotor activity without affecting sociability. Both WAY-100635, a selective antagonist of 5-HT1A receptor, and L-368899, a selective oxytocin receptor antagonist, abolish prosocial effects of MDMA. Differential quantitative analysis of brain proteome by isobaric tag for relative and absolute quantification technology (iTRAQ) revealed 21 specific proteins that were highly correlated with sociability, and allowed to distinguish between entactogenic prosocial and hyperlocomotor effects of MDMA on proteome level. Our data suggest particular relevance of neurotransmission mediated by GABA B receptor, as well as proteins involved in energy maintenance for MDMA-induced sociability. Functional association network for differentially expressed proteins in cerebral cortex, hippocampus and amygdala were identified. These results provide new information for understanding the neurobiological substrate of sociability and may help to discover new therapeutic approaches to modulate social behavior in patients suffering from social fear and low sociability.
\end{abstract}

Keywords: Social behavior; proteomics; N-Methyl-3,4-methylenedioxyamphetamine; oxytocin; 5HT1A receptor; entactogens. 


\section{Highlights}

- $\quad$ MDMA (3 mg/kg i.p.) is able to promote sociability without hyperlocomotion in some mice.

- $\quad$ MDMA elevates locomotor activity without affecting social preference in other mice.

- $\quad$ Antagonists of both 5-HT1A and oxytocin receptors abolish prosocial effect of MDMA.

- $\quad 21$ proteins highly correlating with sociability were identified by iTRAQ 8-plex.

- $\quad$ Proteins related to different responses to the same MDMA treatment were revealed.

\section{Abbreviations}

5-HT1A, serotonin receptor subtype 1a; 5-HT2C, serotonin receptor subtype 2c; FDR, false discovery rate; GHB, gamma-hydroxybutyrate; GPCR, G-protein coupled receptor; iTRAQ, isobaric tag for relative and absolute quantification; LC, liquid chromatography; MDMA, 3,4methylenedioxymethamphetamine; MS, mass spectrometry; PSM, peptide-spectrum match; SERT, 5-HT transporter. 


\section{Introduction}

Social behavior plays a fundamental role in life of many animal species, allowing the interaction between individuals and sharing of experiences, needs, and goals across them (de Waal, 2011). Parental care, pair bonding, emotional convergence, cooperation and aggression are prototypical examples of these activities. Thus, sociability is not restricted to humans, but appears in many species (Decety et al., 2012). In humans, some neuropsychiatric diseases, such as anxiety, posttraumatic stress disorder, autism spectrum disorders, Asperger's syndrome and some cerebral lesions are often characterized by impaired sociability (Caldwell, 2012). The neurobiological substrate underlying sociability has not been yet fully clarified. Brain areas involved in social processes mainly include cortical and limbic structures that are important for cognitive and emotional functions (Blakemore, 2008). The amygdala and cortical areas, such as the posterior superior temporal sulcus, the temporal poles and the medial prefrontal cortex are considered to have a major role in social behavior (Fossati, 2012). Hippocampus is crucial in memory formation and also seems to be important in maintaining social behavior (Decety et al., 2012). Psychoactive drugs that promote social behavior are called "entactogens". Most entactogens are amphetamine derivates, phenethylamines or tryptamines that enhance serotonergic activity in the central nervous system, and the pharmacological properties of entactogens result in behavioral effects that are distinct from classical psychostimulants (Nichols et al., 1986). The first discovered and relatively well-studied entactogen is MDMA (N-Methyl-3,4-methylenedioxyamphetamine, also known as "Ecstasy"), a representative substance for revealing the pharmacological mechanisms of this class of drugs. In humans, MDMA produces euphoria, wellbeing, sociability, self-confidence, feelings of emotional closeness with others, reduced interpersonal defensiveness and extroversion (Vollenweider et al., 1998). Subjects with previously severe post-traumatic stress disorder, who were unresponsive to existing treatments, had symptomatic relief by MDMA-assisted psychotherapy (Mithoefer et al., 2013). However, MDMA and other similar entactogens cannot be used for long-term treatment due to the cardiovascular effects, hyperthermia and neurotoxicity in 
serotonergic terminals among other adverse effects. Therefore, there is strong demand to mimic prosocial effects of entactogens by other approaches that would be, suitable for treatment of patients suffering from social fear and low sociability. For this purpose, it would be crucial to determine the molecular substrates of these prosocial effects of MDMA. The mechanisms involved in the adverse effects of MDMA have been intensively studied over last decades (de la Torre et al., 2004). However, the mechanism of MDMA entactogen-induced sociability remains unclear. The monoamine neurotransmitter serotonin, and two neuropeptides, oxytocin and vasopressin have been consistently linked with the neural regulation of sociability in mammals (Caldwell, 2012). MDMA at a moderate dose $(5 \mathrm{mg} / \mathrm{kg})$ increases sociability, promotes the release of oxytocin and activates hypothalamic oxytocin-containing neurons in rats via an action on serotonin-1A (5-HT1A) receptors (Hunt et al., 2011; Thompson et al., 2007). The influence of MDMA on oxytocin release and its correlation with subjective prosocial feelings has also been demonstrated in humans (Dumont et al., 2009), as well as the impact of 5-HT1A receptor activation in subjective MDMA effects (Hasler et al., 2009). Few studies have already reported the effects of high doses and/or chronic administration of MDMA on brain transcriptome and proteome in rodents (Thiriet et al., 2002; Martínez-Turrillas et al., 2006; Benturquia et al., 2008; van Nieuwenhuijzen et al., 2010; Fernandez-Castillo et al., 2012). However, the data concerning changes of gene/protein expression in the brain after single administration of a low dose of MDMA, relevant to MDMA doses producing entactogenic effects in humans are absent. Most of the previous studies investigating MDMA side effects have evaluated the alterations in transcriptome and proteome many hours (or even days/weeks) after MDMA administration, when entactogenic effect already disappeared. Since the goal of the present study was to investigate the substrate of MDMA of prosocial effect, the proteomic analysis was carried out one hour after MDMA administration, when the behavioral effect of the drug reach the maximum level. Indeed MDMA plasma concentration and behavioral effects reach their maximum in 10 min after systemic administration (i.p.) in mice injection and both significantly decrease 90 min later (Fantegrossi et al., 2009). Considering the large availability of genetically modified mice and the difficulties to carry out similar research in humans, the mouse 
seems the most convenient species to evaluate the genes and/or proteins involved in sociability.

In this study, we used a novel behavioral mouse model of sociability by co-administration of relatively low dose of MDMA together with WAY-1000635, an antagonist for the 5-HT1A receptor, or with L-368899, an oxytocin receptor antagonist, that allowed to distinguish between entactogenic and adverse effects of MDMA. Considering the significant mismatch between the levels of mRNAs and the corresponding proteins (see review of Vogel and Marcotte, 2011), we decided to omit transcriptomic approaches focusing our research on the proteins correlated with behavioral alterations. Therefore, quantitative proteomic analysis of variations in protein expression in cerebral cortex, hippocampus and amygdala from mice exposed to these treatments were used to shed light onto the molecular mechanisms underlying social behavior, which may be helpful to identify new targets for the treatment of social disorders. 


\section{Experimental procedures}

\subsection{Animals}

C57BL/6J mice were purchased from Charles River and were handled for 1 week before starting the experiments. Male mice aged 8-12 weeks were housed four per cage in a temperature $\left(21^{\circ} \mathrm{C} \pm\right.$ $\left.1{ }^{\circ} \mathrm{C}\right)$ and humidity-controlled $(55 \% \pm 10 \%)$ environment. Food and water were available ad libitum. All the experiments were performed during the dark phase of a $12 \mathrm{~h}$ light, $12 \mathrm{~h}$ dark cycle (reverse lighting cycle: light on at 8 p.m. and off at 8 a.m.) under the sodium lamp (McLennan and TaylorJeffs, 2004). All animal procedures followed standard ethical guidelines (European Union Directive 2010/63/EU) and were approved by the local ethical committee (Comitè Ėtic d'Experimentació Animal - Parc de Recerca Biomèdica de Barcelona, CEEA-PRBB).

\subsection{Drugs and treatments}

All drugs and laboratory reagents were obtained from Sigma-Aldrich, if no otherwise specified. MDMA ( $\pm 3,4-$-methylenedioxy-N-methylamphetamine; 1-(1,3-benzodioxol-5-yl)-N-methylpropan-2amine or "Ecstasy") was dissolved in saline, and WAY-100635 and L-368899 in vehicle (2\% Tween-80 and $0.5 \%$ methylcellulose in water). Every mouse received two simultaneous i.p. injections 20 min before the beginning of behavioral tests: MDMA or saline, and WAY-100635, L368899 , or vehicle. MDMA was given at 2, 3, 4 and $6 \mathrm{mg} / \mathrm{kg}$ to determine the minimal active dose (3 mg/kg), which has been used for co-administration with antagonists, WAY-100635 (1 mg/kg, according to Thompson et al., 2007) or L-368899 (1, 3 and $10 \mathrm{mg} / \mathrm{kg})$. Therefore, 13 different acute pharmacological treatments were administered, and, based on the results of these behavioral tests, 6 animal groups were selected for subsequent proteomic analysis (see Table 1). All animals were drug-naïve before the beginning of experiments, and received the drugs just once. All experimental groups were balanced considering the age of animals, and all behavioral tests were performed by researchers blind to the different experimental groups. 


\subsection{Behavioral tests}

Sociability has been investigated using Crawley's three-chamber test as previously described (Moy et al., 2004) with minor modifications. The social testing apparatus was a rectangular, threechambered box fabricated by Universitat Pompeu Fabra Maintenance Service. Each chamber was $20 \mathrm{~cm} \mathrm{~L} \mathrm{x} 40 \mathrm{~cm} \mathrm{~W} \times 22 \mathrm{~cm} \mathrm{H}$. Dividing walls were made from clear Plexiglas, with small circular openings (5 cm in diameter) allowing access into each chamber. Two identical wire cup-like cages, with a bottom diameter of $10 \mathrm{~cm}, 13 \mathrm{~cm}$ in height and bars spaced $1.2 \mathrm{~cm}$, allowing nose contact between the bars, but prevented fighting, were placed inside each side chamber in bilaterally symmetric positions. The test mouse was placed into the middle chamber and was allowed to explore the entire box with empty small wire cages inside for a 10-min habituation session. After the habituation period, an unfamiliar male (stranger), that had no prior contact with the subject mice, was enclosed in one of the cup-like wire cages. The amount of time spent in each chamber and the number of entries into each chamber were evaluated by an observer seated $1.5 \mathrm{~m}$ from the apparatus. The location of the stranger in the left vs right side chamber was systematically alternated between trials. The animals serving as strangers were male C57BL/6J mice that had previously been habituated to placement in the cup-like wire cage. An entry was defined as all four paws in one chamber. "Sociability" is defined as propensity to spend time with another same-sex unfamiliar mouse (stranger), as compared to time spent alone in an identical empty chamber. Sociability index was calculated as (time spent in stranger side chamber - time spent in empty side chamber) / (total time exploring both side chambers). Positive indices mean higher preference for social contacts, whereas negative values indicate avoidance of interactions with social partner. Locomotor activity was measured by counting the total number of entries in both side chambers during the $10 \mathrm{~min}$ test session. After every trial, all chambers and cup-like wire cages were disinfected with CR-36 MURAL spray (J. Collado S.A., Barcelona, Spain), cleaned with $70 \%$ ethanol, dried and ventilated for few min to prevent olfactory cue bias and to ensure proper disinfection. 


\subsection{Protein extraction}

Mice were sacrificed by cervical dislocation and decapitation immediately after behavioral tests (60 min after drugs injection). Brains were rapidly removed, dissected on ice, flash frozen in dry ice and stored at $-80^{\circ} \mathrm{C}$. Proteins and RNA were isolated from cerebral cortices, hippocampi and amygdales using Nucleospin RNA/Protein kit ("Macherey-Nagel”, Düren, Germany). Precipitated protein samples were dissolved in $4 \%$ sodium dodecylsulfate in $0.1 \mathrm{M} \mathrm{HEPES}(\mathrm{pH}=8.5)$ followed by concentration measurement using DC Protein Assay (Bio-Rad Laboratories). Based on pharmacological treatment and results of behavioral tests, 7 different animal groups were identified, since the "MDMA (3)" group was divided in two separated subgroups, "MDMA high sociability" and "MDMA low sociability". As donwstream ITRAQ analysis required quite high amount of total protein, the samples from 5 representative animals were pooled together in equal proportions for every group and brain region.

\section{5. iTRAQ labeling and MS analysis}

Proteomic analyses were performed in the CRG/UPF Proteomics Unit (Parc de Recerca Biomèdica, Barcelona, Spain). Two hundred mg of every pooled protein sample were subjected to trypsin (Promega, USA) digestion following the filter-aided sample preparation protocol as described previously (Wisniewski et al., 2009). Peptides generated in the digestion were desalted with a cartridge Oasis HLB cartridge (Waters, USA), evaporated to dryness and dissolved in 0.5 $\mathrm{mol} / \mathrm{L}$ triethylammoniumbicarbonate and labeled with iTRAQ-8 reagents (Applied Biosystems, USA) at lysines and terminal amine groups following the manufacturer's protocol. The eight isobaric labels have a nominal mass of $305 \mathrm{Da}$ and consist of a "reporter" functional group $(113,114,115$, 116, 117, 118, 119 or $121 \mathrm{~m} / \mathrm{z})$, a "balance" group (192-184 Da), and a peptide reactive group. Each of the eight chemical labels dissociates in the mass spectrometer to produce one of the discrete reporter ions, which is measured in an MS/MS scan and provides the peaks used for peptide quantitation. In these experiments, seven experimental samples were labeled with iTRAQ reagents from 113 to 119 , whereas the mixture of all seven treatment groups was labeled with the 
iTRAQ reagent 121 and served as an internal standard. The pooled sample containing labeled peptides was desalted with a cartridge Oasis HLB cartridge (Waters, USA) evaporated to dryness and dissolved in $1 \mathrm{~mL}$ of $100 \% \mathrm{~A}$ (90\% acetonitrile in $0.1 \%$ acetic acid). Fractionation of peptides by ERLIC was done on an Agilent 1100 system equipped with a PolyWAX LP TM Column $(200 \times 2.1 \mathrm{~mm}, 5 \mu \mathrm{m} ; 300-\mathrm{A}$, PolyLC) with a multistep gradient consisting in a $10 \mathrm{~min}$ isocratic at $100 \% \mathrm{~A}, 40 \mathrm{~min}$ of $0-30 \% \mathrm{~B}(30 \%$ acetonitrile in $0.1 \%$ formic acid), followed by 40 min of $30-100 \%$ $\mathrm{B}$, and finally 100 min maintenance at isocratic $100 \% \mathrm{~B}$ with a flow rate of $0.5 \mathrm{~mL} / \mathrm{min}$. A total of 10 fractions were collected. The ERLIC fractions were evaporated to dryness and re-dissolved in 10 $\mu \mathrm{L}$ of $0.1 \%$ formic acid prior to MS. For LC-MS/MS analysis, $2 \mu \mathrm{L}$ of each fraction was run on an LTQ-Orbitrap Velos (Thermo Fisher Scientific Inc., USA) fitted with a nanospray source (Thermo Fisher Scientific Inc., USA) previous nano-LC separation in a EasyLC system (Proxeon). Peptides were separated in a reverse phase column, $75 \mu \mathrm{m}$ x $150 \mathrm{~mm}$ (Nikkyo Technos Co. Ltd., Tokyo, Japan) with a gradient of 5 to $35 \%$ acetonitrile with $0.1 \%$ formic acid in 120 min at a flow of 0.3 $\mu \mathrm{L} / \mathrm{min}$. The Orbitrap Velos was operated in positive ion mode with nanospray voltage set at $2.2 \mathrm{kV}$ and source temperature at $325{ }^{\circ} \mathrm{C}$. The instrument was externally calibrated using Ultramark 1621 for the FT mass analyzer. An internal calibration was performed using the background polysiloxane ion signal at $\mathrm{m} / \mathrm{z} 445.120025$ as the calibrant. The instrument was operated in Data Dependent Acquisition mode. In all experiments, full MS scans were acquired over a mass range of $\mathrm{m} / \mathrm{z} 350$ 2000 with detection in the Orbitrap mass analyzer at a resolution setting of 60000 . Fragment ion spectra produced via high-energy collision dissociation were acquired in the Orbitrap mass analyzer with a resolution setting of 7500 for the mass range of $\mathrm{m} / \mathrm{z}$ 100-2000. In each cycle of Data Dependent Acquisition analysis, following each survey scan the top ten most intense ions with multiple charged ions above a threshold ion count of 10000 were selected for fragmentation at normalized collision energy of $45 \%$. All data were acquired with Xcalibur 2.1 software (Thermo Fisher Scientific Inc., USA). 


\subsection{Protein identification and quantification}

Protein identification and quantitation was performed by Proteome Discoverer software v.1.4.0.288 (Thermo Fisher Scientific Inc., USA) using MASCOT v2.3 (Matrix Science, USA) as search engine. Data were processed by a search against a mouse Swiss-Prot database that included the most common contaminants. Carbamidomethylation for cysteines, iTRAQ (8plex) for lysines and Nterminal were set as fixed modification. Acetylation in protein $\mathrm{N}$-terminal, oxidation of methionine and iTRAQ (8plex) for tyrosines were set as variable modifications. Peptide tolerance was $7 \mathrm{ppm}$ in MS and $20 \mathrm{mmu}$ in MS/MS mode; maximum number of missed cleavages was set at 3 . Peptides were filtered based on the FDR (False Discovery Rate) lower than 5\%. Protein quantification (ratio and its variability for every detected protein) was calculated from several detected peptides matching the same protein (PSMs, peptide-spectrum matches) using Proteome Discoverer software module for iTRAQ quantitation, and only proteins containing at least two spectra were used for quantification. All obtained ratios for the ITRAQ reporters were normalized on protein median for each sample to avoid any possible bias due to different intensities of iTRAQ channels. Relative protein abundance was calculated from protein ratios, where the relative abundance for every protein in "MDMA high sociability" group (iTRAQ reporter 115) was set equal to 1.

\subsection{Bioinformatics and pathway analysis}

All statistically significant and differentially expressed proteins were searched against the differentially expressed genes in the KEGG pathways (Kyoto Encyclopedia of Genes and Genomes, http://www.genome.jp/kegg, Release 66.1 from May 1, 2013) and in PANTHER pathways (Protein ANalysis THrough Evolutionary Relationships, http://www.pantherdb.org, v8.1, release date June 1, 2013). The same lists of altered proteins were examined against the corresponding genomic data repositories in NextBio Disease Atlas (http://www.nextbio.com). MDMA-induced sociability represents a behavioral phenomenon opposing to social withdrawal in autism spectrum disorder, post-traumatic stress disorder, social anxiety and fear, childhood disorder of conduct and emotion and social environment related disease. Therefore, only those 
proteins found to be changed in opposite direction to the alterations revealed in these diseases were taken into account in "MDMA high sociability" group. Finally, the analysis for functional protein association network (protein interactome) was carried out for every analyzed brain region using STRING algorithm (http://string.embl.de, v9.05, Franceschini et al., 2013) with required confidence set at medium level.

\subsection{Statistical analysis}

Sociability index and locomotor activity were compared among animal groups by one-way ANOVA test ( 0.05 confidence level). When applicable, post-hoc analysis of each of these variables was performed using a Dunnett's test vs. "Saline" or vs. "MDMA high sociability" group. For iTRAQ analysis, the alteration in protein ratios among different samples was tested for all detected peptides matching the same protein (peptide-spectrum matches, PSMs) by one-way ANOVA test (0.05 confidence level) followed by Dunnett's post-hoc vs. "MDMA high sociability" group when appropriate. 


\section{Results}

\subsection{MDMA at relatively low dose induces differential effects on mouse sociability and locomotion.}

Minimal active dose of MDMA in mice was determined by acute administration of a range of low to moderate doses (from 2 to $6 \mathrm{mg} / \mathrm{kg}$, Table 1). MDMA significantly elevated the sociability index at the dose of $3 \mathrm{mg} / \mathrm{kg}$ (i.p.). Therefore, this dose was chosen for the co-administration with antagonists. Neither WAY-100635, a selective 5-HT1A antagonist nor L-368899, centrally active selective oxytocin receptor antagonist, modified social behavior or locomotion when given alone. WAY-100635 given at $1 \mathrm{mg} / \mathrm{kg}$ significantly attenuated the social preference produced by MDMA (3 $\mathrm{mg} / \mathrm{kg}$ ), without any significant effect on locomotion. L-368899 when administered at $10 \mathrm{mg} / \mathrm{kg}$ partially blocked prosocial effect of MDMA, whereas lower doses of this antagonist were ineffective (Table 1). Data on time spent by test mice in the middle chamber and in both side chambers (empty one or with stranger mouse) are presented in supplementary Fig. SF1. Based on these results, 6 groups receiving different acute pharmacological treatments, namely "Saline", "MDMA (3)", "WAY100635”, “MDMA + WAY-100635”, “L-368899 (10)" and “MDMA + L-368899 (10)”, were chosen for downstream proteomic analysis (Table 1). A high variability among animals was observed in the behavioral effects of MDMA given at the prosocial active dose $(3 \mathrm{mg} / \mathrm{kg})$. Our main interest was to elucidate the possible mechanism of such a different MDMA response. For this purpose, we carried out the median split for "MDMA (3)" group and separated this group in two subgroups, "MDMA low sociability", that included 5 animals with the lowest sociability, and "MDMA high sociability", consisting of 5 animals with the highest sociability. To ensure equal impact of animals in every experimental group included in proteomic analysis, we selected 5 representative animals (sociability around the median for the whole group) from all other groups; the results on sociability and locomotor activity for those selected animals are presented on Fig. 1. These results are similar to those found in the whole groups of mice shown in Table 1. Indeed, sociability index for the 
"MDMA high sociability" group was significantly higher than in any other group, and 5-HT1A receptor antagonist, as well as oxytocin receptor antagonist, both rescued normal sociability after MDMA administration. Surprisingly, the separation of animals based on MDMA sociability revealed that elevated locomotor activity was only observed in "MDMA low sociability", whereas MDMA did not modify locomotion in highly sociable animals. This result underlines the relevance of the differential analysis of two animal groups with different sociability MDMA responses that receive the same pharmacological treatment for studying the specific mechanisms involved in prosocial and hyperlocomotor effects of MDMA.

\subsection{Quantitative profiling by iTRAQ reveals proteome correlates of behavioral responses to MDMA treatment.}

If the abundance of specific tissue protein correlates with the data on sociability, the corresponding gene might be considered as potential candidate regulating prosocial behavior. Such correlation was rated as "significant" when the protein is differently expressed in "Saline" and at least 3 from the 5 remaining control groups vs. "MDMA high sociability" group (general selection criterion). An additional more strict criterion was also applied to select the proteins with the highest correlation, when the abundance of the protein in "MDMA high sociability" group was significantly different in the same direction from the two most important control groups, ("Saline" and "MDMA low sociability"), and also significantly altered in the same direction from at least 3 of the remaining groups. Most important results of iTRAQ profiling are presented on the Fig. 2. In cortex, two proteins of particular relevance, that reached the strict selection criterion, were identified: Lipid phosphate phosphohydrolase 3 (Ppap2b) and Gamma-aminobutyric acid type B receptor subunit 1 (Gabbr1), which levels were lower in highly sociable animals than in any other group. In amygdala, three proteins were identified matching the strict selection criterion: Syntaxin-binding protein 1 (Stxbp1) and Microtubule-associated protein 4 (Mtap4) were expressed stronger in "MDMA high sociability" than in other groups, whereas Phosphatidate cytidylyltransferase 2 (Cds2) expressed 
lower in "MDMA high sociability". In hippocampus, 15 other proteins were identified using the strict selection criteria: Calcium-binding protein 39 (Cab39), BRICK1 (Brk1), Neuroglycan C (Cspg5), Microtubule-associated protein 4 (Mtap4), Proteasome activator complex subunit 1 (Psme1), Brain glucose transporter type 1 (S/c2a1), COP9 signalosome complex subunit 8 (Cops8), N-myc downstream-regulated gene 2 protein (Ndrg2) and alpha-1 chain of Tropomyosin (Tpm1), which expression was lower in "MDMA high sociability" group than in other groups, whereas the level of ATP-dependent RNA helicase DDX3Y (Ddx3y), Probable ATP-dependent RNA helicase DDX5 $(D d x 5)$, Dihydropyrimidinase-related protein 3 (Dpys/3), Mitochondrial NADP-dependent isocitrate dehydrogenase (Idh2), RuvB-like 1 protein (Ruvb/1), MAGUK p55 subfamily member 6 (Mpp6) and WD repeat-containing protein 37 (Wdr37) was higher in animals from "MDMA high sociability" group. All proteins significantly correlated with sociability by matching the first general selection criterion described above are listed in supplementary tables (Tab. S1 for cortex: 20 proteins, Tab. S2 for hippocampus: 47 proteins, and Tab. S3 for amygdala: 16 proteins). In addition, proteins representing different behavioral respond to the same MDMA treatment revealed by significant changes between "MDMA low sociability" and "MDMA high sociability" groups are also listed in supplementary tables (Tab. S4 for cortex: 80 proteins, Tab. S5 for hippocampus: 75 proteins and Tab. S6 for amygdala: 34 proteins). In general, the revealed sets of differentially expressed proteins for the three analyzed brain regions are quite distinct, in agreement with the different functions of cerebral cortex, hippocampus and amygdala, and allows hypothesizing the presence of several region-specific neuronal mechanisms of prosocial behavior.

\subsection{Pathways related to MDMA-induced sociability.}

In silico analysis by STRING identified several protein interactome networks among proteins related to MDMA-induced sociability (Fig. 3). In cortex, the protein-protein interactions are revealed for 32 from 102 altered proteins with reported $P$-Value from Hypergeometric test equal to $7.90 \times 10^{-10}$ (Fig. 3a). STRING algorithm predicted the participation in this network for another protein, the $26 \mathrm{~S}$ proteasome non-ATPase regulatory subunit 7 (Psmd7) as "white node" with probability higher than 
0.999. Psmd7 was absent in MASCOT identification results since its amount was lower than detection limit for LC-MS/MS assay. In hippocampus, the connectivity was even higher since 50 out of 122 total proteins form one functional interaction network, and further seven proteins participate in another network (reported $P$-Value $=2.15 \times 10^{-14}$ ) (Fig. 3b). In amygdala, there are two interactome clusters (reported $P$-Value $=2.33 \times 10^{-15}$ ): a first consists of 11 , and another of six proteins, out of total 50 differentially regulated proteins (Fig. 3c). Our proteomic analysis revealed multiple alterations in pathways involved in energy maintenance (glycolysis, sugar metabolism; oxidative phosphorylation, dopaminergic signaling) related to social behavior. Another important pathway found to be related to sociability is gamma-aminobutyric acid (GABA) signaling. According to the iTRAQ data, one of most correlating with sociability proteins was the subunit 1 of $\mathrm{GABA}_{B}$ receptor, which expression level in cortices of highly sociable mice was significantly lower than in all other animal groups (see supplementary table S1). Moreover, the level of other proteins involved in GABA signaling - Gng2 and Gng4 from hippocampus, and Gng3 and Prkar2b from amygdala - was significantly lower in "MDMA high sociability" group than in "MDMA low sociability" (supplementary tables S5 and S6). Other pathways, overrepresented in analyzed brain regions, include GPCR signaling, synaptic vesicle cycle, WNT signaling and regulation of protein turnover (transcription, translation, modification of proteins and their proteasomal degradation). Several important postsynaptic proteins are also found to be differentially expressed: Disks large-associated protein 3 (Dlgap3) and protein SHANK3 (Shank3) are up-regulated in hippocampi of highly sociable mice, and Ras GTPase-activating protein SynGAP (Syngap1) was differently expressed in hippocampi and amygdales of mice with distinct behavioral response to the same MDMA treatment. 


\section{Discussion}

We have translated from the rat to the mouse a pharmacological approach previously reported to evaluate sociability (Thompson et al., 2007) and described the proteins correlated with MDMAinduced social behavior and with susceptibility to MDMA treatment in mice. MDMA is known to promote social behavior in humans (Vollenweider et al., 1998) and rats (Thompson et al., 2007), although the data about MDMA-induced sociability in mice were absent until now. By using the Crawley's three-chamber test we demonstrate for the first time that MDMA also induces prosocial behavior in mouse. The use of this behavioral model in mice simplifies the complicated experimental procedures previously used in rats, such as adjacent lying or anogenital investigation (Thompson et al., 2007). In addition, the possibility to evaluate the sociability induced by MDMA in mice opens new possible research approaches by using the different lines of genetically modified mice now available. The mechanisms of MDMA action have been mainly investigated with selective agonists or antagonists of the potential receptors involved in its pharmacological responses, and more recently, using genetically modified mice (Stove et al., 2010). Multiple studies associate social fear and sociability with modulation of the inhibitory serotonergic 5-HT1A receptor (Akimova et al., 2009), and our findings on pharmacological blockade of this receptor on MDMA-induced sociability support this hypothesis. In agreement, animal studies revealed behavioral, autonomic, and endocrinological manifestations of an anxiety-like phenotype in 5-HT1A receptor knockout mice, and a wide range of preclinical research and clinical trials in humans have involved 5-HT1A with pathological manifestations of anxiety (Akimova et al., 2009). Pharmacological data obtained with 5-HT1A agonists and antagonists allowed to associate the polymorphisms of 5-HT1A receptor gene with increased anxiety scores in humans (Akimova et al., 2009). Other members of serotonin

system, primarily 5-HT transporter (SERT) and 5-HT2C receptor, have also been shown to participate in the regulation of social behavior. Thus, the SERT blocker fluoxetine and the 5-HT1A receptor partial-agonist buspirone enhanced social interactions in mice (Gould et al., 2011). In addition, the 5-HT2B/2C agonist mCPP decreased sociability in mice, and the 5-HT2 agonist RO 
60-0175 induced anxiogenic responses that were dependent on the presence of SERT (Moya et al., 2011). Oxytocin and vasopressin regulate social recognition and affiliation, anxiety, mood and aggression in many species (Baumgartner et al., 2008; Ramos et al., 2013), and seems to play an essential role in prosocial behavior in humans (Kosfeld et al., 2005). Although oxytocin and vasopressin do not cross the blood-brain barrier, several studies have reported that nasal administration of oxytocin modifies human behavior: alters social attention, appraisal, trust and generosity. Other researchers claim that prosocial effects of oxytocin are limited to individuals with supportive family backgrounds, and other failed to reach any behavioral effect after oxytocin intranasal administration (see review of Guastella and MacLeod, 2012). Pharmacological blockade of $\mathrm{V} 1_{A} R$ vasopressin receptor completely reverses oxytocin- and vasopressin-induced prosocial behavior whereas oxytocin antagonist did not affect these responses (Ramos et al., 2013). However, $V 1_{A} R$ vasopressin receptor antagonism only partially blocks the prosocial effects of (Ramos et al., 2013) and the selective oxytocin antagonist L-368899 that has very low affinity for vasopressin $\mathrm{V} 1_{\mathrm{A}}$ and $\mathrm{V} 2$ receptors (Williams et al., 1994). Therefore, oxytocin plays a major role in the prosocial effects of MDMA, although vasopressin receptors could also be involved. Several preclinical double-blinded, randomized placebo-controlled studies showed that MDMA significantly increased plasma oxytocin level together with subjective prosocial behavior in humans, and prosocial feelings were robustly and positively correlated with variations in oxytocin plasma level in these subjects (Carson et al., 2013). Taken together, these observations and our results outline the crucial role of serotonin and oxytocin for the regulation of MDMA-induced prosocial behavior. Some proteins related to oxytocin, vasopressin, 5-HT and dopamine could be missing in our proteomic results since the detection limit of high ITRAQ could lead to the misrepresentation of any lowabundant regulatory proteins.

Some authors have hypothesized that low sociability might be influenced in particular cases by a lack of energy necessary for neuronal activity (Careau and Garland, 2012). Social behavior is important, but it does not have the highest priority among other behavioral processes. In case of low energy availability, brain attenuates the activity of all functions that are not crucial for survival, 
including social behavior. This hypothesis is supported by our findings showing that many proteins involved in energy maintenance significantly correlate their expression with sociability.

In addition, our proteomic data suggest particular relevance of GABA-mediated neurotransmission in MDMA-induced prosocial behavior, which is in agreement with multiple reports about recreational abuse of GABA agonists, including the $\mathrm{GABA}_{B}$ agonist 4-hydroxybutanoic acid (GHB, gammahydroxybutyrate) or "liquid Ecstasy" claimed to increase sociability such as MDMA (Gonzalez and Nutt, 2005). Several studies have reported a crosstalk between serotonin and GABA system. Thus, the serotonin releaser MDMA depressed the inhibitory postsynaptic potential of GABAB receptor by activating of 5-HT1B receptor (Federici et al., 2007), and increased GABA efflux in the ventral tegmental brain area (Bankson and Yamamoto, 2004), which correlates with our behavioral data. Furthermore, muscimol, a $G_{A B A}$ agonist, and baclofen, a $G_{A B A}$ agonist, prevented hyperthermia, hyperlocomotion, tachycardia and hypertension induced by MDMA (Bexis et al., 2004; Rusyniak et al., 2008). Baclofen increased sociability in C57BL/6J mice in a dose-dependent manner (Amikishieva and Semendyaeva, 2007) and reversed social deficit in NDMA-NR1 ${ }^{\text {neo/- }}$ mice (Gandal et al., 2012). According to NIH database on clinical trials (http://www.clinicaltrials.gov), there are several ongoing clinical trials to use baclofen and its R-enantiomer arbaclofen for the treatment of social withdrawal in patients with autism spectrum disorder and Fragile $\mathrm{X}$ syndrome that are associated with abnormalities in social behavior. Our results support the interest of $\mathrm{GABA}_{B}$ receptor as a promising target for medical purposes in patients with sociability related disorders.

The expression of proteins related to signaling mediated by G-protein coupled receptors (GPCR) was found to be significantly altered in high sociability mice. Serotonin and oxytocin act via various G-protein coupled receptors, and the release of these two neurotransmitters by MDMA administration must affect the subsequent G-protein signaling downstream. In addition, MDMA and many of its metabolites also directly bind several GPCRs (Ray, 2010), and the administration of drugs like MDMA, WAY-100635 and L-368899 activates multiple drug efflux systems and catabolic pathways, many of which are G-protein dependent.

According to the search on NextBio Disease Atlas (http://www.nextbio.com/b/search/da.nb) and 
AutismKB database (http://autismkb.cbi.pku.edu.cn/, Xu et al., 2012), 85\% of proteins highly correlating with sociability (17 out of 20 ), and $70 \%$ of all other proteins found to be differently expressed in our experimental conditions correspond to the human homolog genes involved in autism spectrum disorder, post-traumatic stress disorder, anxiety, childhood disorder of conduct and emotion, and social environment related disease. Among these proteins, post-synaptic proteins SHANK3 and SynGAP were identified as highly involved in autism by many researchers (Peça et al., 2011). The in silico network analyses of proteome interactome revealed that alterations in these two proteins correlate with idiopathic autism spectrum disorder (Sakai et al., 2011). Disks largeassociated protein 3 (Dlgap3), identified here as correlating with sociability, was reported earlier as related to Fragile $X$ syndrome (Schutt et al., 2009). The high homology between our findings and clinical data points to the relevance of the present data for the translation to the human pathological conditions. Future electrophysiological or behavioral approach on other experimental models would be of interest to confirm the significance of the present iTRAQ results. In addition, we revealed here tissue-specific sets of proteins representing different behavioral responses to the same MDMA treatment in mice, which could also provide support to explain the difference in responses to MDMA administration in humans.

In conclusion, using a novel pharmacological mouse model for the study of social behavior, we identified proteins and functional networks correlating with sociability. These data may help to discover new genetic and pharmacological tools for the modulation of social behavior that would be suitable for long-term treatment of patients suffering from sociability disorders. 


\section{Table}

Tab. 1 Results of the three-chamber sociability test for all tested animals.

\begin{tabular}{|c|c|c|c|c|c|c|c|c|c|}
\hline \multirow{2}{*}{ Group name } & \multirow{2}{*}{ Injection 1} & \multirow{2}{*}{ Injection 2} & \multirow{2}{*}{$\begin{array}{l}\text { Number of } \\
\text { animals }\end{array}$} & \multicolumn{3}{|c|}{ Sociability index } & \multicolumn{3}{|c|}{ Locomotor activity } \\
\hline & & & & Mean & S.E.M. & $\begin{array}{l}\text { Difference vs } \\
\text { Saline group }\end{array}$ & Mean & S.E.M. & $\begin{array}{l}\text { Difference vs } \\
\text { Saline group }\end{array}$ \\
\hline Saline & Saline & Vehicle & 16 & 0.12 & 0.08 & - & 12.1 & 1.3 & - \\
\hline$M D M A(2)$ & MDMA (2 mg/kg) & Vehicle & 10 & 0.23 & 0.08 & NS & 14.9 & 1.7 & NS \\
\hline MDMA (3) & MDMA (3 mg/kg) & Vehicle & 15 & 0.33 & 0.07 & $p<0.05$ & 18.2 & 1.8 & $p<0.01$ \\
\hline MDMA (4) & MDMA (4 mg/kg) & Vehicle & 10 & 0.11 & 0.13 & NS & 12.7 & 2.1 & NS \\
\hline$M D M A(6)$ & MDMA (6 mg/kg) & Vehicle & 8 & 0.23 & 0.17 & NS & 7.1 & 1.4 & $p<0.05$ \\
\hline WAY-100635 & Saline & WAY-100635 (10 mg/kg) & 9 & 0.14 & 0.07 & NS & 11.8 & 1.0 & NS \\
\hline$M D M A+W A Y-100635$ & MDMA (3 mg/kg) & WAY-100635 (10 mg/kg) & 7 & -0.08 & 0.09 & NS & 18.0 & 0.8 & $p<0.01$ \\
\hline L-368899 (1) & Saline & L-368899 (1mg/kg) & 6 & 0.37 & 0.12 & NS & 12.2 & 1.7 & NS \\
\hline$M D M A+L-368899$ (1) & MDMA (3 mg/kg) & L-368899 (1mg/kg) & 8 & 0.36 & 0.08 & $p<0.05$ & 14.8 & 1.7 & NS \\
\hline L-368899 (3) & Saline & L-368899 (3mg/kg) & 8 & 0.11 & 0.16 & NS & 13.1 & 1.0 & NS \\
\hline$M D M A+L-368899$ & MDMA (3 mg/kg) & L-368899 (3mg/kg) & 9 & 0.39 & 0.09 & $p<0.05$ & 12.4 & 0.9 & NS \\
\hline$L-368899(10)$ & Saline & L-368899 (10 mg/kg) & 8 & 0.01 & 0.14 & NS & 11.4 & 1.0 & NS \\
\hline$M D M A+L-368899(10)$ & MDMA (3 mg/kg) & L-368899 (10 mg/kg) & 7 & 0.15 & 0.18 & NS & 13.3 & 1.9 & NS \\
\hline
\end{tabular}

Animal groups selected for subsequent proteomic analysis are presented in bold script. 


\section{Figures.}

Fig. 1.
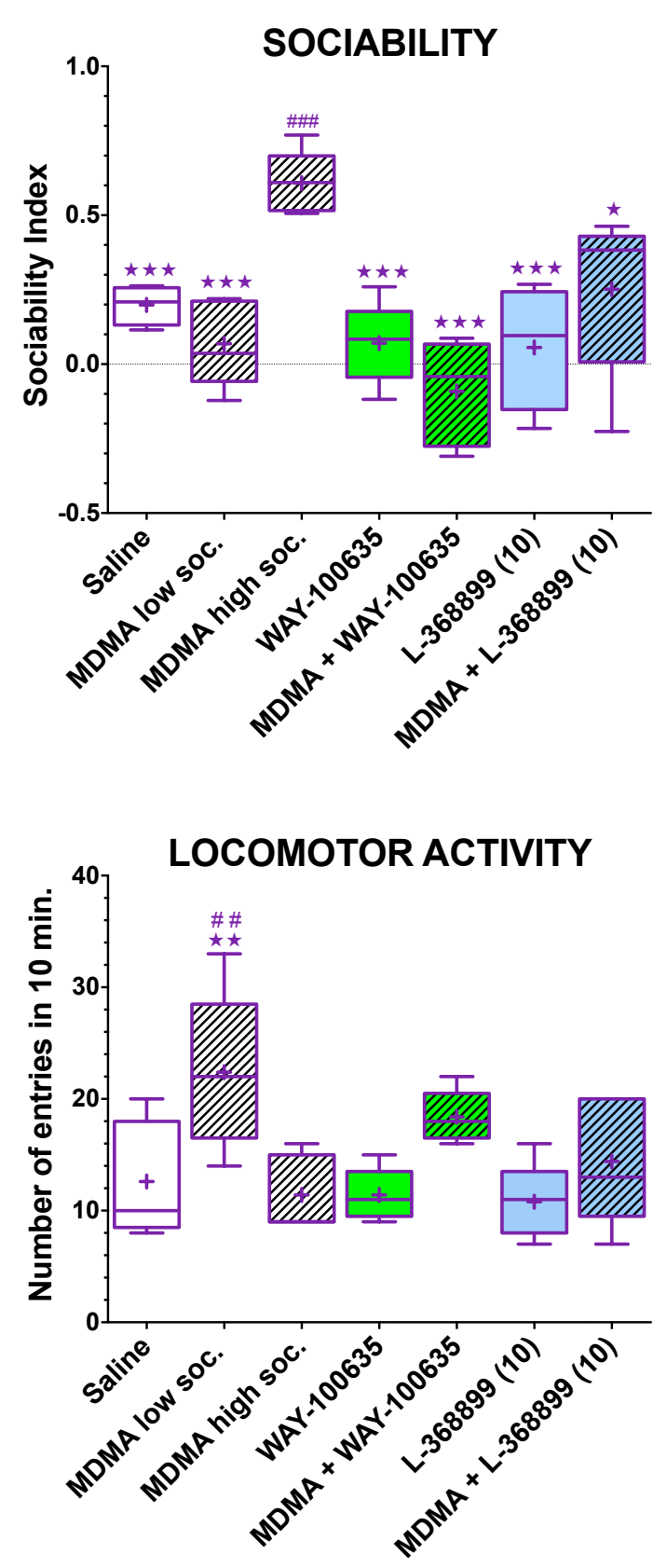

Results of three-chamber sociability test for the mice selected for subsequent proteomic profiling. Data presented as boxes showing interquartile range of values with the horizontal line inside plotted at the median, whiskers showing minimal and maximal values, and the crosses pointing on the means. ${ }^{*} p<0.05,{ }^{* *} p<0.01$ and ${ }^{* * *} p<0.005$, significantly different vs. "MDMA high sociability" group. ${ }^{\#} p<0.01$ and ${ }^{\# \#} p<0.005$, significantly different vs. "Saline" group (Dunnett's post-hoc). 
Fig. 2.

\section{Relative protein abundances}
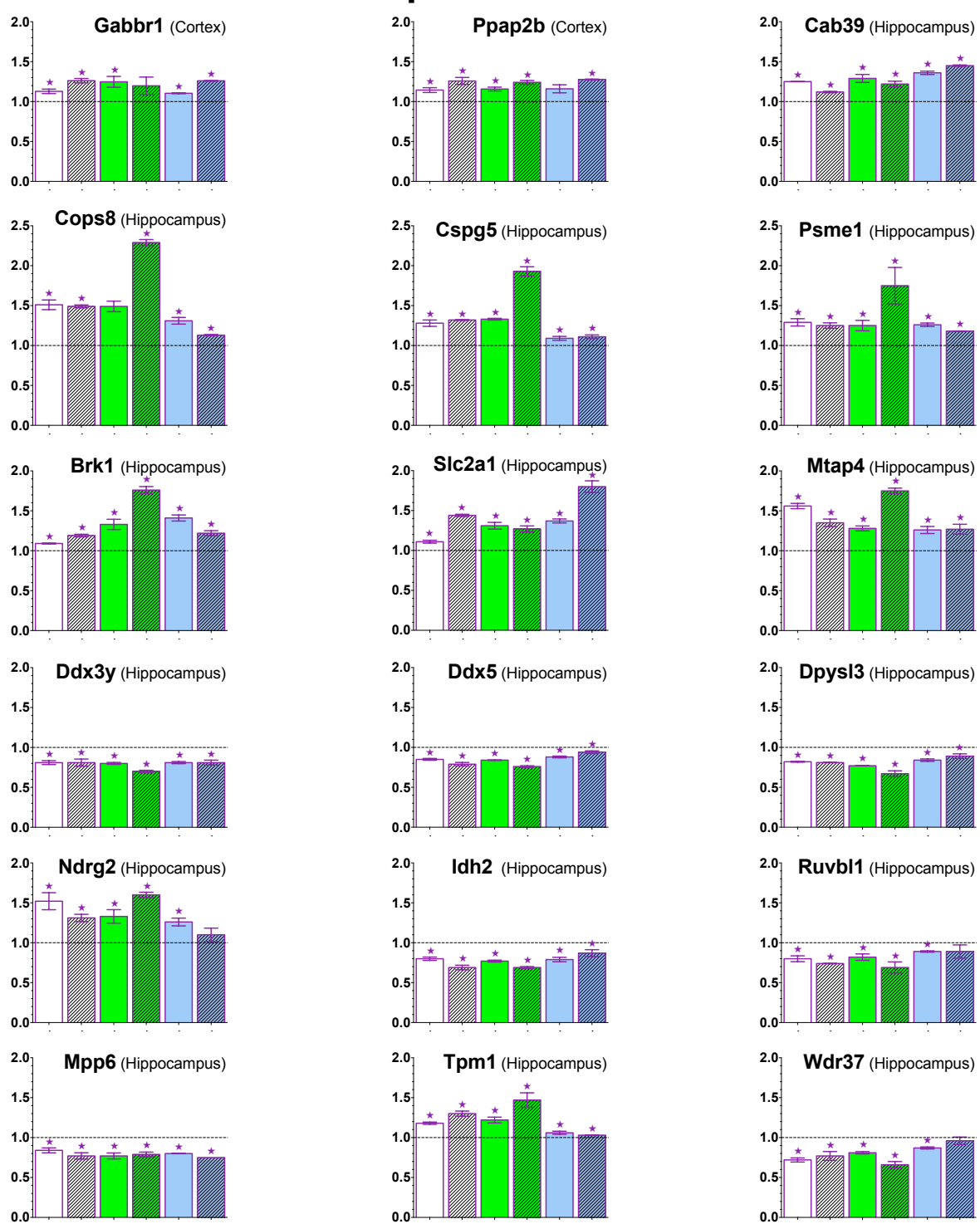

Wdr37 (Hippocampus)
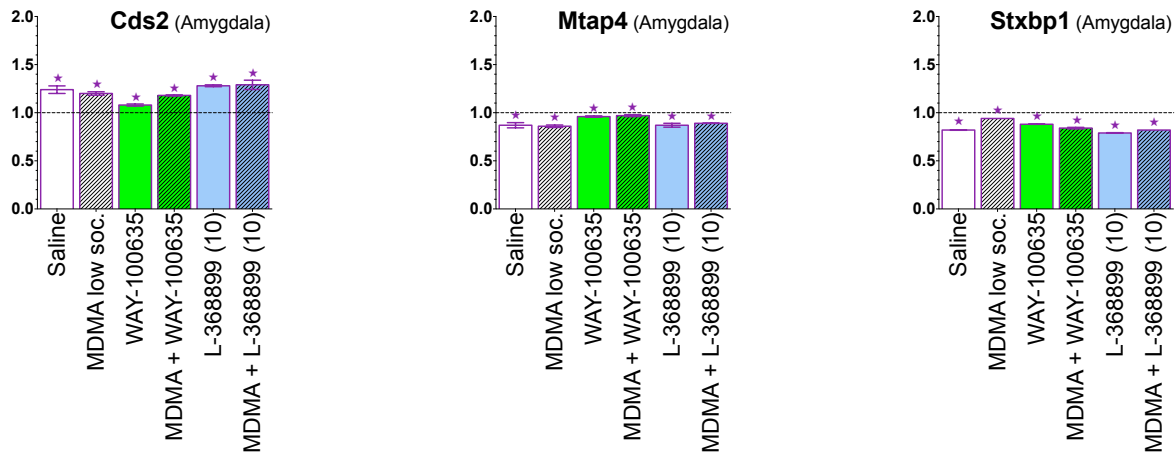

Results of ITRAQ analysis for proteins with highest correlation between their abundance and prosocial behavior. Data presented as Ratio \pm Variability related to "MDMA high sociability" group (dotted line at 1.0). 
Fig. 3

\section{A (Cortex)}

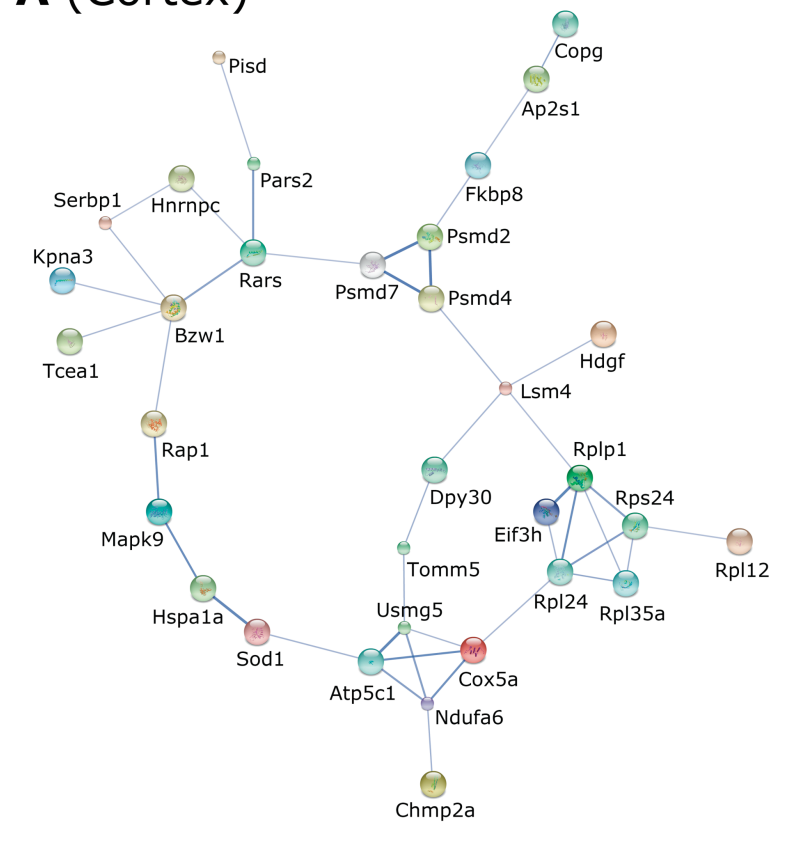

\section{C (Amygdala)}
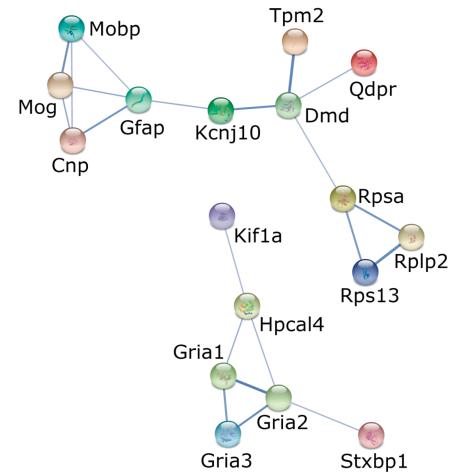

\section{B (Hippocampus)}

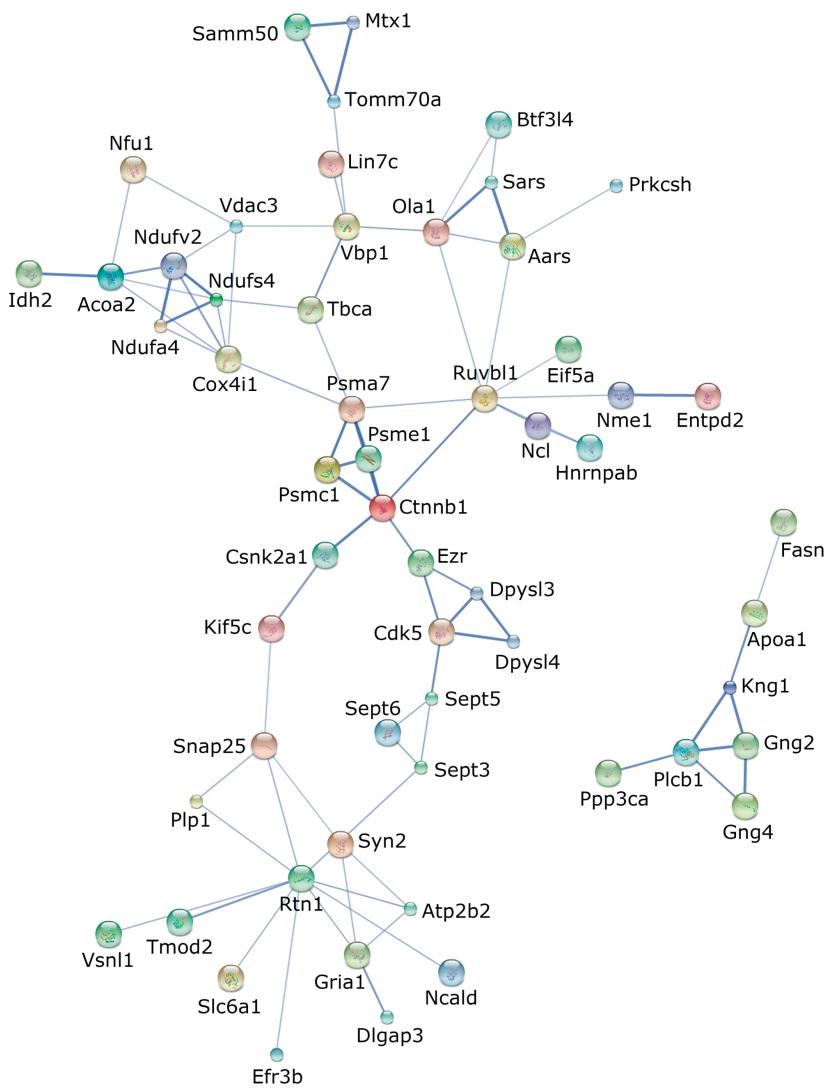

Functional association network for differentially expressed proteins. (A) Cortex. (B) Hippocampus. (C) Amygdala. 


\section{Supplementary Data}

A supplementary figure SF1 and six supplementary tables (S1-S6) are available:

Fig. SF1. Time spent by test mouse in every chamber of social testing apparatus.

Table S1. Cortex: Proteins differently expressed in "Saline" and at least three other groups vs. "MDMA high sociability" group.

Table S2. Hippocampus: Proteins differently expressed in "Saline" and at least three other groups vs. "MDMA high sociability" group.

Table S3. Amygdala: Proteins differently expressed in "Saline" and at least three other groups vs. "MDMA high sociability" group.

Table S4. Cortex: Proteins differently expressed in "MDMA low sociability" vs. "MDMA high sociability" group.

Table S5. Hippocampus: Proteins differently expressed in "MDMA low sociability" vs. "MDMA high sociability" group.

Table S6. Amygdala: Proteins differently expressed in "MDMA low sociability" vs. "MDMA high sociability" group. 


\section{References}

Akimova, E., Lanzenberger, R., Kasper, S., 2009. The serotonin-1A receptor in anxiety disorders. Biol Psychiatry 66, 627-635.

Amikishieva, A. V., Semendyaeva, S. N., 2007. Effects of baclofen on anxiety, sexual motivation, and olfactory perception in male mice in different psychoemotional states. Neurosci Behav Physiol 37, 929-937.

Bankson, M. G., Yamamoto, B. K., 2004. Serotonin-GABA interactions modulate MDMA-induced mesolimbic dopamine release. J Neurochem 91, 852-859.

Baumgartner, T., Heinrichs, M., Vonlanthen, A., Fischbacher, U., Fehr, E., 2008. Oxytocin shapes the neural circuitry of trust and trust adaptation in humans. Neuron 58, 639-650.

Benturquia, N., Courtin, C., Noble, F., Marie-Claire, C., 2008. Involvement of D1 dopamine receptor in MDMA-induced locomotor activity and striatal gene expression in mice. Brain Res 1211, 1-5.

Bexis, S., Phillis, B. D., Ong, J., White, J. M., Irvine, R. J., 2004. Baclofen prevents MDMA-induced rise in core body temperature in rats. Drug Alcohol Depend 74, 89-96.

Blakemore, S. J., 2008. The social brain in adolescence. Nat Rev Neurosci 9, 267-277.

Caldwell, H. K., 2012. Neurobiology of sociability. Adv Exp Med Biol 739, 187-205.

Careau, V., Garland, T., Jr., 2012. Performance, personality, and energetics: correlation, causation, and mechanism. Physiol Biochem Zool 85, 543-571.

Carson, D. S., Guastella, A. J., Taylor, E. R., McGregor, I. S., 2013. A brief history of oxytocin and its role in modulating psychostimulant effects. J Psychopharmacol 27, 231-247.

de la Torre, R., Farre, M., Roset, P. N., Pizarro, N., Abanades, S., Segura, M., Segura, J., Cami, J., 2004. Human pharmacology of MDMA: pharmacokinetics, metabolism, and disposition. Ther Drug Monit 26, 137-144.

de Waal, F. B., 2011. What is an animal emotion? Ann N Y Acad Sci 1224, 191-206.

Decety, J., Norman, G. J., Berntson, G. G., Cacioppo, J. T., 2012. A neurobehavioral evolutionary perspective on the mechanisms underlying empathy. Prog Neurobiol 98, 38-48.

Dumont, G. J., Sweep, F. C., van der Steen, R., Hermsen, R., Donders, A. R., Touw, D. J., van Gerven, J. M., Buitelaar, J. K., Verkes, R. J., 2009. Increased oxytocin concentrations and prosocial feelings in humans after ecstasy (3,4-methylenedioxymethamphetamine) administration. Soc Neurosci 4, 359-366. 
Fantegrossi, W. E., Murai, N., Mathúna, B. O., Pizarro, N., de la Torre, R., 2009. Discriminative stimulus effects of 3,4-methylenedioxymethamphetamine and its enantiomers in mice: pharmacokinetic considerations. J Pharmacol Exp Ther 329, 1006-1015.

Federici, M., Sebastianelli, L., Natoli, S., Bernardi, G., Mercuri, N. B., 2007. Electrophysiologic changes in ventral midbrain dopaminergic neurons resulting from (+/-) -3,4methylenedioxymethamphetamine (MDMA-"Ecstasy"). Biol Psychiatry 62, 680-686.

Fernandez-Castillo, N., Orejarena, M. J., Ribases, M., Blanco, E., Casas, M., Robledo, P., Maldonado, R., Cormand, B., 2012. Active and passive MDMA ('ecstasy') intake induces differential transcriptional changes in the mouse brain. Genes Brain Behav 11, 38-51.

Fossati, P., 2012. Neural correlates of emotion processing: from emotional to social brain. Eur Neuropsychopharmacol 22 Suppl 3, S487-491.

Franceschini, A., Szklarczyk, D., Frankild, S., Kuhn, M., Simonovic, M., Roth, A., Lin, J., Minguez, P., Bork, P., von Mering, C., Jensen, L. J., 2013. STRING v9.1: protein-protein interaction networks, with increased coverage and integration. Nucleic Acids Res 41, D808-815.

Gandal, M. J., Sisti, J., Klook, K., Ortinski, P. I., Leitman, V., Liang, Y., Thieu, T., Anderson, R., Pierce, R. C., Jonak, G., Gur, R. E., Carlson, G., Siegel, S. J., 2012. GABAB-mediated rescue of altered excitatory-inhibitory balance, gamma synchrony and behavioral deficits following constitutive NMDAR-hypofunction. Transl Psychiatry 2, e142.

Gonzalez, A., Nutt, D. J., 2005. Gamma hydroxy butyrate abuse and dependency. J Psychopharmacol 19, 195-204.

Gould, G. G., Hensler, J. G., Burke, T. F., Benno, R. H., Onaivi, E. S., Daws, L. C., 2011. Density and function of central serotonin (5-HT) transporters, 5-HT1A and 5-HT2A receptors, and effects of their targeting on BTBR T+tf/J mouse social behavior. J Neurochem 116, 291-303.

Guastella, A. J., MacLeod, C., 2012. A critical review of the influence of oxytocin nasal spray on social cognition in humans: evidence and future directions. Horm Behav 61, 410-418.

Hasler, F., Studerus, E., Lindner, K., Ludewig, S., Vollenweider, F. X., 2009. Investigation of serotonin-1A receptor function in the human psychopharmacology of MDMA. J Psychopharmacol 23, 923-935.

Hunt, G. E., McGregor, I. S., Cornish, J. L., Callaghan, P. D., 2011. MDMA-induced c-Fos expression in oxytocin-containing neurons is blocked by pretreatment with the 5-HT-1A receptor antagonist WAY 100635. Brain Res Bull 86, 65-73. 
Kosfeld, M., Heinrichs, M., Zak, P. J., Fischbacher, U., Fehr, E., 2005. Oxytocin increases trust in humans. Nature 435, 673-676.

Martinez-Turrillas, R., Moyano, S., Del Rio, J., Frechilla, D., 2006. Differential effects of 3,4methylenedioxymethamphetamine (MDMA, "ecstasy") on BDNF mRNA expression in rat frontal cortex and hippocampus. Neurosci Lett 402, 126-130.

McLennan, I. S., Taylor-Jeffs, J., 2004. The use of sodium lamps to brightly illuminate mouse houses during their dark phases. Laboratory Animals 38, 384-392.

Mithoefer, M. C., Wagner, M. T., Mithoefer, A. T., Jerome, L., Martin, S. F., Yazar-Klosinski, B., Michel, Y., Brewerton, T. D., Doblin, R., 2013. Durability of improvement in post-traumatic stress disorder symptoms and absence of harmful effects or drug dependency after 3,4methylenedioxymethamphetamine-assisted psychotherapy: a prospective long-term follow-up study. J Psychopharmacol 27, 28-39.

Moy, S. S., Nadler, J. J., Perez, A., Barbaro, R. P., Johns, J. M., Magnuson, T. R., Piven, J., Crawley, J. N., 2004. Sociability and preference for social novelty in five inbred strains: an approach to assess autistic-like behavior in mice. Genes Brain Behav 3, 287-302.

Moya, P. R., Fox, M. A., Jensen, C. L., Laporte, J. L., French, H. T., Wendland, J. R., Murphy, D. L., 2011. Altered 5-HT2C receptor agonist-induced responses and 5-HT2C receptor RNA editing in the amygdala of serotonin transporter knockout mice. BMC Pharmacol 11, 3.

Nichols, D. E., Hoffman, A. J., Oberlender, R. A., Jacob, P., 3rd, Shulgin, A. T., 1986. Derivatives of 1-(1,3-benzodioxol-5-yl)-2-butanamine: representatives of a novel therapeutic class. $\mathrm{J}$ Med Chem 29, 2009-2015.

Peça, J., Ting, J., Feng, G., 2011. SnapShot: Autism and the synapse. Cell 147, 706, 706.e701.

Ramos, L., Hicks, C., Kevin, R., Caminer, A., Narlawar, R., Kassiou, M., McGregor, I. S., 2013. Acute prosocial effects of oxytocin and vasopressin when given alone or in combination with 3,4-methylenedioxymethamphetamine in rats: involvement of the V1A receptor. Neuropsychopharmacology 38, 2249-2259.

Ray, T. S., 2010. Psychedelics and the human receptorome. PLoS One 5, e9019.

Rusyniak, D. E., Zaretskaia, M. V., Zaretsky, D. V., DiMicco, J. A., 2008. Microinjection of muscimol into the dorsomedial hypothalamus suppresses MDMA-evoked sympathetic and behavioral responses. Brain Res 1226, 116-123. 
Sakai, Y., Shaw, C. A., Dawson, B. C., Dugas, D. V., Al-Mohtaseb, Z., Hill, D. E., Zoghbi, H. Y., 2011. Protein interactome reveals converging molecular pathways among autism disorders. Sci Transl Med 3, 86ra49.

Schutt, J., Falley, K., Richter, D., Kreienkamp, H. J., Kindler, S., 2009. Fragile X mental retardation protein regulates the levels of scaffold proteins and glutamate receptors in postsynaptic densities. J Biol Chem 284, 25479-25487.

Stove, C. P., De Letter, E. A., Piette, M. H., Lambert, W. E., 2010. Mice in ecstasy: advanced animal models in the study of MDMA. Curr Pharm Biotechnol 11, 421-433.

Thiriet, N., Ladenheim, B., McCoy, M. T., Cadet, J. L., 2002. Analysis of ecstasy (MDMA)-induced transcriptional responses in the rat cortex. Faseb j 16, 1887-1894.

Thompson, M. R., Callaghan, P. D., Hunt, G. E., Cornish, J. L., McGregor, I. S., 2007. A role for oxytocin and $5-\mathrm{HT}(1 \mathrm{~A})$ receptors in the prosocial effects of 3,4 methylenedioxymethamphetamine ("ecstasy"). Neuroscience 146, 509-514.

van Nieuwenhuijzen, P. S., Kashem, M. A., Matsumoto, I., Hunt, G. E., McGregor, I. S., 2010. A long hangover from party drugs: residual proteomic changes in the hippocampus of rats 8 weeks after gamma-hydroxybutyrate (GHB), 3,4-methylenedioxymethamphetamine (MDMA) or their combination. Neurochem Int 56, 871-877.

Vogel, C., Marcotte, E. M., 2012. Insights into the regulation of protein abundance from proteomic and transcriptomic analyses. Nat Rev Genet 13, 227-232.

Vollenweider, F. X., Gamma, A., Liechti, M., Huber, T., 1998. Psychological and cardiovascular effects and short-term sequelae of MDMA ("ecstasy") in MDMA-naive healthy volunteers. Neuropsychopharmacology 19, 241-251.

Williams, P. D., Anderson, P. S., Ball, R. G., Bock, M. G., Carroll, L., Chiu, S. H., Clineschmidt, B. V., Culberson, J. C., Erb, J. M., Evans, B. E., 1994. 1-((7,7-Dimethyl-2(S)-(2(S)-amino-4(methylsulfonyl)butyramido)bicyclo [2.2.1]-heptan-1(S)-yl)methyl)sulfonyl)-4-(2-methylphenyl) piperazine (L-368,899): an orally bioavailable, non-peptide oxytocin antagonist with potential utility for managing preterm labor. J Med Chem 37, 565-571.

Wisniewski, J. R., Zougman, A., Nagaraj, N., Mann, M., 2009. Universal sample preparation method for proteome analysis. Nature Methods 6, 359-362.

Xu, L. M., Li, J. R., Huang, Y., Zhao, M., Tang, X., Wei, L., 2012. AutismKB: an evidence-based knowledgebase of autism genetics. Nucleic Acids Res 40, D1016-1022. 


\section{TIME SPENT IN EVERY CHAMBER}

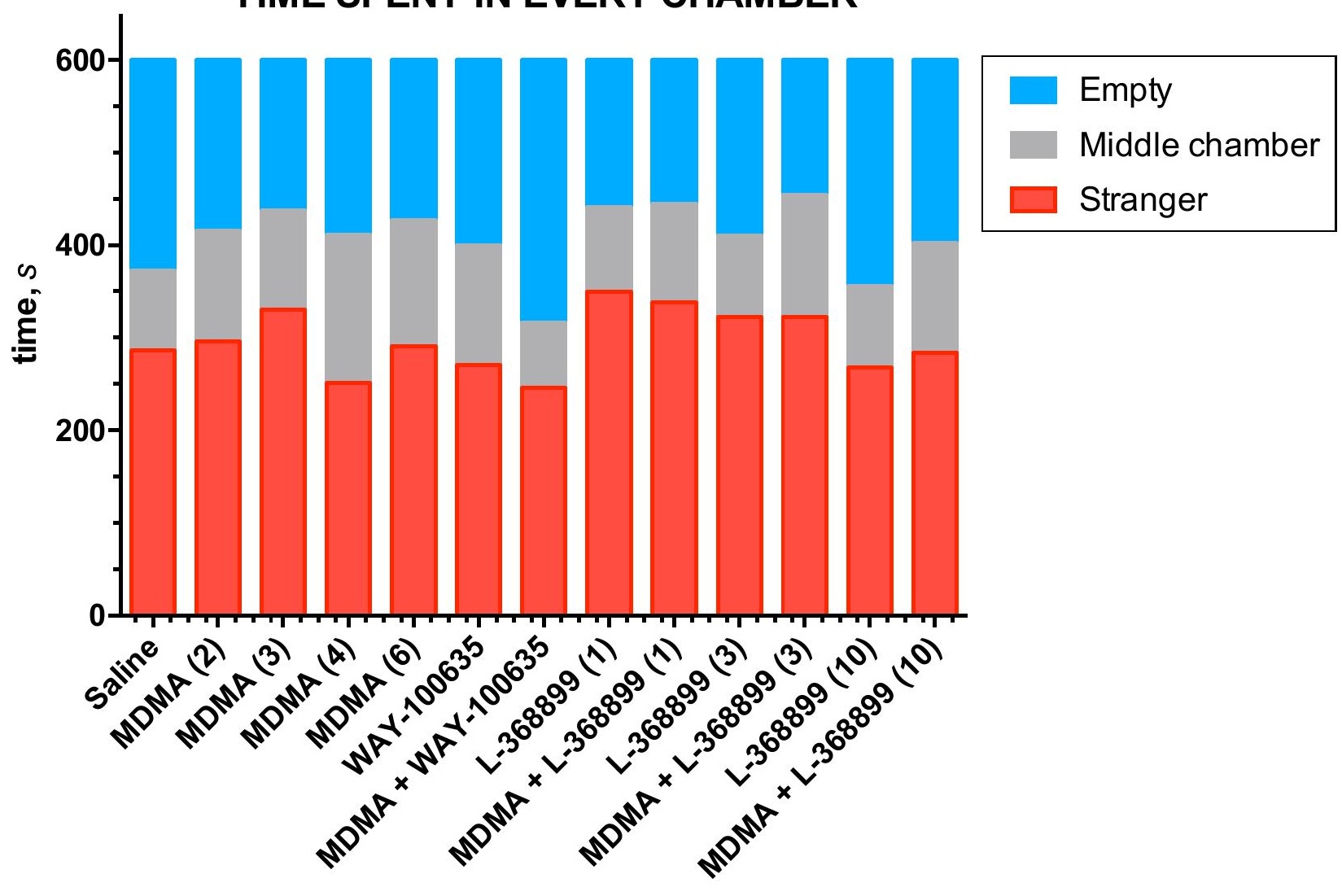


Tab. S1 Cortex: Proteins differently expressed in "Saline" and at least three other groups vs. "MDMA high sociability" group.

\begin{tabular}{|c|c|c|c|c|c|c|c|c|c|c|c|c|c|c|c|}
\hline \multirow[b]{2}{*}{$\begin{array}{c}\text { UniProt } \\
\text { Accession }\end{array}$} & \multirow[b]{2}{*}{ Gene name } & \multirow[b]{2}{*}{$\begin{array}{l}\text { Mascot } \\
\text { Score }\end{array}$} & \multirow[b]{2}{*}{$\begin{array}{l}\text { \# PSMs } \\
\text { detected }\end{array}$} & \multicolumn{2}{|l|}{ Saline } & \multicolumn{2}{|c|}{ MDMA low soc. } & \multicolumn{2}{|c|}{ WAY-100635 } & \multicolumn{2}{|c|}{ MDMA + WAY-100635 } & \multicolumn{2}{|c|}{ L-368899 } & \multicolumn{2}{|c|}{ MDMA + L-368899 } \\
\hline & & & & $\begin{array}{l}\text { Ratio to "MDMA } \\
\text { high soc." group }\end{array}$ & $\begin{array}{c}\text { Variability, } \\
{[\%]}\end{array}$ & $\begin{array}{l}\text { Ratio to "MDMA } \\
\text { high soc." group }\end{array}$ & $\begin{array}{c}\text { Variability, } \\
{[\%]}\end{array}$ & $\begin{array}{l}\text { Ratio to "MDMA } \\
\text { high soc." group }\end{array}$ & $\begin{array}{c}\text { Variability, } \\
{[\%]}\end{array}$ & $\begin{array}{l}\text { Ratio to "MDMA } \\
\text { high soc." group }\end{array}$ & $\begin{array}{c}\text { Variability, } \\
{[\%]}\end{array}$ & $\begin{array}{l}\text { Ratio to "MDMA } \\
\text { high soc." group }\end{array}$ & $\begin{array}{c}\text { Variability, } \\
{[\%]}\end{array}$ & $\begin{array}{l}\text { Ratio to "MDMA } \\
\text { high soc." group }\end{array}$ & $\begin{array}{c}\text { Variability, } \\
{[\%]}\end{array}$ \\
\hline Q8VCY8 & Lppr2 & 37 & 2 & $1.50^{*}$ & 35.3 & $1.22^{*}$ & 3.7 & $1.33^{*}$ & 5.9 & $1.32 *$ & 7.9 & 1.15 & 25.7 & 1.25 & 30.8 \\
\hline Q9WTU6 & Mapk9 & 28 & 3 & $1.20^{*}$ & 0.3 & $1.08^{*}$ & 1.8 & 1.05 & 4.6 & $1.04 *$ & 0.1 & 1.08 & 5.1 & $1.25^{*}$ & 0.1 \\
\hline P12658 & Calb1 & 49 & 5 & $1.18^{*}$ & 2.6 & $1.15^{*}$ & 1.7 & $1.14^{*}$ & 2.4 & 1.11 & 4.6 & $1.18^{*}$ & 2.0 & 1.10 & 6.4 \\
\hline Q9Z2H2 & Rgs6 & 47 & 3 & $1.16^{*}$ & 5.2 & $1.19 *$ & 3.8 & $1.23^{*}$ & 11.3 & $1.11^{*}$ & 5.0 & 1.03 & 5.6 & 1.10 & 5.5 \\
\hline Q99L13 & Hibadh & 58 & 3 & $1.16^{*}$ & 1.2 & $1.17^{*}$ & 6.7 & 1.11 & 5.7 & $1.15^{*}$ & 2.8 & $1.22^{*}$ & 9.0 & 1.17 & 13.6 \\
\hline Q99JY8 & Ppap2b & 102 & 3 & $1.14 *$ & 4.5 & $1.26 *$ & 6.0 & $1.16 *$ & 3.5 & $1.24 *$ & 3.3 & 1.16 & 7.5 & $1.28 *$ & 0.6 \\
\hline Q91V36 & Nrbp2 & 35 & 3 & $1.13^{*}$ & 2.1 & $1.20^{*}$ & 3.2 & 0.98 & 9.3 & 1.07 & 12.4 & $1.02^{*}$ & 0.6 & $1.20^{*}$ & 5.3 \\
\hline Q9WV18 & Gabbr1 & 30 & 3 & 1.13* & 4.3 & $1.26 *$ & 3.7 & $1.25 *$ & 9.4 & 1.20 & 15.7 & $1.10 *$ & 0.9 & $1.26 *$ & 0.6 \\
\hline Q99JG2 & Gpr3기1 & 90 & 7 & $1.11^{*}$ & 2.4 & $1.12^{*}$ & 4.3 & $1.63^{*}$ & 5.2 & $1.48^{*}$ & 3.6 & 1.04 & 3.0 & 1.20 & 13.1 \\
\hline P35803 & $M 6-b$ & 25 & 3 & $1.10^{*}$ & 1.5 & 1.69 & 31.3 & 2.03 & 30.3 & $1.73^{*}$ & 5.9 & $2.74 *$ & 14.8 & $1.88^{*}$ & 1.2 \\
\hline P55012 & S/c12a2 & 38 & 2 & $1.09 *$ & 0.8 & 1.27 & 13.7 & $1.17^{*}$ & 4.9 & $1.15^{*}$ & 4.8 & $1.02^{*}$ & 0.1 & 1.11 & 7.0 \\
\hline Q8C419 & Gpr158 & 62 & 6 & $1.08^{*}$ & 0.9 & 1.19 & 11.1 & $1.13^{*}$ & 4.4 & $1.16^{*}$ & 7.0 & 1.04 & 2.0 & $1.12^{*}$ & 4.9 \\
\hline P13439 & Umps & 22 & 2 & $0.91^{*}$ & 4.8 & $0.83^{*}$ & 1.7 & 0.86 & 14.2 & $0.89 *$ & 3.4 & 1.04 & 5.2 & $0.84 *$ & 1.5 \\
\hline Q91XV3 & Basp1 & 35 & 2 & $0.90 *$ & 3.1 & 0.83 & 9.6 & $0.54^{*}$ & 1.5 & $0.87^{*}$ & 3.4 & $0.95 *$ & 1.5 & $1.11^{*}$ & 0.7 \\
\hline Q9CQZ5 & Ndufa6 & 30 & 3 & $0.89 *$ & 4.2 & $0.84 *$ & 4.8 & $0.93 *$ & 0.5 & 0.95 & 3.9 & $0.96 *$ & 2.0 & 0.95 & 3.5 \\
\hline P35979 & Rpl12 & 50 & 2 & $0.88^{*}$ & 5.3 & $0.81^{*}$ & 10.4 & $0.93 *$ & 4.3 & $0.91^{*}$ & 0.7 & 0.99 & 10.9 & 0.95 & 24.8 \\
\hline Q61696 & Hspa1a & 52 & 3 & $0.88^{*}$ & 0.2 & $0.87 *$ & 6.4 & 0.99 & 3.4 & $0.90^{*}$ & 1.6 & $0.95 *$ & 1.1 & 0.76 & 24.0 \\
\hline Q60899 & Elavl2 & 33 & 2 & $0.85^{*}$ & 8.1 & $0.76^{*}$ & 10.4 & 0.91 & 8.6 & $0.87^{*}$ & 6.7 & 0.96 & 5.9 & $0.88^{*}$ & 0.4 \\
\hline Q99LT0 & Dpy30 & 39 & 2 & $0.85 *$ & 8.0 & $0.83^{*}$ & 0.0 & $0.79 *$ & 2.8 & 0.88 & 7.6 & 0.89 & 8.4 & $0.79 *$ & 2.8 \\
\hline Q91YE6 & Ipo9 & 33 & 2 & $0.77 *$ & 13.6 & $0.64 *$ & 20.6 & 0.78 & 21.1 & $0.77 *$ & 14.4 & $0.71 *$ & 11.7 & $0.79 *$ & 6.0 \\
\hline
\end{tabular}

Data presented as relative proteins abundances, significantly different values are marked with * (confidence level 0.05).

Proteins with the highest correlation between their abundance and prosocial behavior are shown in bold. 
Tab. S2 Hippocampus: Proteins differently expressed in "Saline" and at least three other groups vs. "MDMA high sociability" group.

\begin{tabular}{|c|c|c|c|c|c|c|c|c|c|c|c|c|c|c|c|}
\hline \multirow[b]{2}{*}{$\begin{array}{c}\text { UniProt } \\
\text { Accession }\end{array}$} & \multirow[b]{2}{*}{ Gene name } & \multirow[b]{2}{*}{$\begin{array}{l}\text { Mascot } \\
\text { Score }\end{array}$} & \multirow[b]{2}{*}{$\begin{array}{l}\text { \# PSMs } \\
\text { detected }\end{array}$} & \multicolumn{2}{|l|}{ Saline } & \multicolumn{2}{|c|}{ MDMA low soc. } & \multicolumn{2}{|c|}{ WAY-100635 } & \multicolumn{2}{|c|}{ MDMA + WAY-100635 } & \multicolumn{2}{|c|}{ L-368899 } & \multicolumn{2}{|c|}{ MDMA + L-368899 } \\
\hline & & & & $\begin{array}{l}\text { Ratio to "MDMA } \\
\text { high soc." group }\end{array}$ & $\begin{array}{c}\text { Variability, } \\
{[\%]}\end{array}$ & $\begin{array}{l}\text { Ratio to "MDMA } \\
\text { high soc." group }\end{array}$ & $\begin{array}{c}\text { Variability, } \\
{[\%]}\end{array}$ & $\begin{array}{l}\text { Ratio to "MDMA } \\
\text { high soc." group }\end{array}$ & $\begin{array}{c}\text { Variability, } \\
{[\%]}\end{array}$ & $\begin{array}{l}\text { Ratio to "MDMA } \\
\text { high soc." group }\end{array}$ & $\begin{array}{c}\text { Variability, } \\
{[\%]}\end{array}$ & $\begin{array}{l}\text { Ratio to "MDMA } \\
\text { high soc." group }\end{array}$ & $\begin{array}{c}\text { Variability, } \\
{[\%]}\end{array}$ & $\begin{array}{l}\text { Ratio to "MDMA } \\
\text { high soc." group }\end{array}$ & $\begin{array}{c}\text { Variability, } \\
{[\%]}\end{array}$ \\
\hline P27546 & Mtap4 & 45 & 3 & $1.56 *$ & 3.7 & $1.35 *$ & 6.0 & $1.28 *$ & 4.1 & $1.75 *$ & 3.4 & $1.26 *$ & 6.1 & $1.27 *$ & 8.4 \\
\hline Q9QYG0 & Ndrg2 & 125 & 6 & $1.52 *$ & 17.2 & $1.31 *$ & 8.5 & $1.33 *$ & 15.6 & $1.60 *$ & 5.1 & $1.26 *$ & 9.4 & 1.10 & 18.6 \\
\hline Q8VBV7 & Cops8 & 35 & 2 & $1.51 *$ & 5.7 & $1.49 *$ & 1.7 & $1.49 *$ & 6.3 & 2.29* & 2.3 & $1.31 *$ & 4.5 & $1.13 *$ & 1.0 \\
\hline Q9Z2U0 & Psma7 & 57 & 3 & $1.29 *$ & 7.0 & 1.05 & 4.9 & $1.21^{*}$ & 4.4 & $1.23 *$ & 0.9 & $1.18^{*}$ & 0.3 & $1.16^{*}$ & 4.3 \\
\hline P97371 & Psme1 & 61 & 4 & $1.29 *$ & 7.1 & $1.25 *$ & 5.5 & $1.25 *$ & 10.5 & $1.75 *$ & 26.0 & $1.26 *$ & 3.4 & 1.18* & 0.5 \\
\hline Q71M36 & Cspg5 & 45 & 3 & $1.28 *$ & 5.4 & $1.32^{*}$ & 0.7 & $1.33 *$ & 1.3 & $1.93 *$ & 5.1 & $1.09 *$ & 3.8 & $1.11 *$ & 3.5 \\
\hline Q9JL62 & Gltp & 85 & 5 & $1.27 *$ & 10.3 & $1.32 *$ & 3.3 & $1.22 *$ & 1.5 & $1.72 *$ & 10.6 & 1.05 & 16.2 & 1.00 & 9.6 \\
\hline Q9JKK7 & Tmod2 & 116 & 6 & $1.25^{*}$ & 10.2 & $1.32 *$ & 2.5 & $1.26^{*}$ & 1.1 & $1.43 *$ & 3.9 & $1.26^{*}$ & 2.8 & 1.12 & 11.9 \\
\hline Q06138 & Cab39 & 78 & 4 & $1.25 *$ & 0.2 & $1.12^{*}$ & 1.5 & $1.29 *$ & 7.7 & $1.22 *$ & 5.8 & $1.36 *$ & 3.1 & $1.45 *$ & 1.2 \\
\hline Q8R395 & Commd5 & 37 & 2 & $1.24 *$ & 1.3 & $1.34 *$ & 10.9 & $1.13^{*}$ & 2.5 & $1.38^{*}$ & 4.2 & 1.00 & 2.0 & 0.86 & 15.3 \\
\hline P47802 & $M t x 1$ & 48 & 2 & $1.24 *$ & 7.8 & $1.26 *$ & 5.5 & $1.33^{*}$ & 4.3 & $1.47^{*}$ & 1.4 & $1.29 *$ & 2.3 & $1.34 *$ & 3.2 \\
\hline Q9QZ23 & Nfu1 & 55 & 2 & $1.23^{*}$ & 3.9 & $1.15^{*}$ & 4.5 & $1.29 *$ & 1.7 & $1.66^{*}$ & 11.1 & $1.04 *$ & 1.8 & 0.90 & 10.2 \\
\hline Q62393 & Tpd52 & 71 & 3 & $1.23^{*}$ & 1.5 & $1.25^{*}$ & 1.6 & $1.29 *$ & 6.9 & $1.74 *$ & 3.9 & 1.04 & 2.9 & 0.94 & 10.5 \\
\hline Q63912 & Omg & 57 & 3 & $1.21^{*}$ & 2.3 & $1.36^{*}$ & 4.7 & $1.32 *$ & 1.5 & $1.96 *$ & 4.6 & 1.10 & 17.7 & 0.89 & 18.3 \\
\hline O55026 & Entpd2 & 64 & 3 & $1.21^{*}$ & 0.9 & $1.28^{*}$ & 5.3 & $1.25^{*}$ & 5.7 & $1.57^{*}$ & 1.6 & 0.99 & 1.3 & 1.01 & 10.8 \\
\hline P58771 & Tpm1 & 107 & 6 & $1.18 *$ & 2.9 & $1.30 *$ & 6.1 & $1.22 *$ & 7.3 & $1.47 *$ & 15.2 & $1.06 *$ & 4.6 & $1.03 *$ & 0.7 \\
\hline P15532 & Nme1 & 74 & 4 & $1.16^{*}$ & 0.4 & $1.23^{*}$ & 6.9 & $1.22 *$ & 3.5 & $1.60 *$ & 5.6 & $1.10^{*}$ & 2.4 & $0.94 *$ & 0.7 \\
\hline Q8VIM9 & Irgq & 37 & 2 & $1.13^{*}$ & 2.5 & 1.15 & 9.1 & $1.18^{*}$ & 0.6 & $1.68 *$ & 9.3 & $1.18^{*}$ & 1.4 & 1.04 & 2.7 \\
\hline Q91X97 & Ncald & 256 & 13 & $1.12^{*}$ & 2.8 & $1.11^{*}$ & 2.8 & $1.23^{*}$ & 8.8 & $1.39 *$ & 12.6 & 1.06 & 6.9 & 1.05 & 3.6 \\
\hline Q8C419 & Gpr158 & 72 & 4 & $1.12^{*}$ & 4.7 & $1.24 *$ & 0.2 & $1.17^{*}$ & 3.4 & $1.68^{*}$ & 1.9 & 1.00 & 6.1 & 1.00 & 17.9 \\
\hline P17809 & Slc2a1 & 39 & 4 & 1.11* & 3.3 & $1.44^{*}$ & 1.9 & $1.31 *$ & 6.4 & $1.27 *$ & 5.9 & $1.37 *$ & 3.6 & $1.80 *$ & 8.1 \\
\hline Q91VR8 & Brk1 & 41 & 3 & $1.09 *$ & 1.0 & 1.19* & 2.3 & $1.33 *$ & 8.4 & $1.76 *$ & 4.3 & $1.41 *$ & 4.7 & $1.22^{*}$ & 4.4 \\
\hline Q9Z1S5 & Sept3 & 49 & 4 & $0.91^{*}$ & 2.1 & $0.83^{*}$ & 7.3 & 0.99 & 0.2 & $1.04 *$ & 1.9 & 0.90 & 7.6 & $0.88^{*}$ & 4.0 \\
\hline Q9CPX6 & $\operatorname{Atg} 3$ & 54 & 3 & $0.90^{*}$ & 1.2 & $0.85^{*}$ & 6.8 & 0.87 & 7.7 & $0.87 *$ & 1.9 & 0.99 & 2.4 & $0.85^{*}$ & 5.4 \\
\hline Q9JII6 & Akr1a1 & 42 & 3 & $0.89 *$ & 2.7 & $0.75^{*}$ & 3.9 & $0.78^{*}$ & 2.2 & 0.83 & 19.9 & $0.95 *$ & 1.5 & $0.83^{*}$ & 7.5 \\
\hline P26638 & Sars & 49 & 3 & $0.88^{*}$ & 6.8 & $0.83^{*}$ & 5.3 & $0.87^{*}$ & 3.3 & $0.71^{*}$ & 4.0 & $0.90 *$ & 2.9 & 0.98 & 1.8 \\
\hline Q9D1G5 & Lrrc57 & 40 & 2 & $0.88^{*}$ & 3.6 & $0.81^{*}$ & 2.4 & $0.93^{*}$ & 3.7 & 0.95 & 6.6 & 0.91 & 4.9 & $0.87^{*}$ & 1.5 \\
\hline Q8BGQ7 & Aars & 189 & 6 & $0.87 *$ & 5.7 & $0.87^{*}$ & 6.6 & $0.86 *$ & 3.4 & $0.69 *$ & 16.3 & 0.97 & 7.1 & 0.98 & 14.6 \\
\hline Q9CZ30 & Ola1 & 52 & 4 & $0.86^{*}$ & 7.5 & $0.76^{*}$ & 3.8 & $0.85^{*}$ & 3.8 & $0.78^{*}$ & 3.2 & 0.85 & 8.5 & 0.86 & 4.4 \\
\hline Q9CWS0 & Ddah1 & 59 & 2 & $0.85^{*}$ & 0.3 & 0.92 & 7.4 & $0.90 *$ & 1.7 & $0.95 *$ & 1.4 & $0.70^{*}$ & 2.3 & $0.73^{*}$ & 2.1 \\
\hline
\end{tabular}


Tab. S2 Hippocampus: Proteins differently expressed in "Saline" and at least three other groups vs. "MDMA high sociability" group.

\begin{tabular}{|c|c|c|c|c|c|c|c|c|c|c|c|c|c|c|c|}
\hline \multirow[b]{2}{*}{$\begin{array}{c}\text { UniProt } \\
\text { Accession }\end{array}$} & \multirow[b]{2}{*}{ Gene name } & \multirow[b]{2}{*}{$\begin{array}{l}\text { Mascot } \\
\text { Score }\end{array}$} & \multirow[b]{2}{*}{$\begin{array}{l}\text { \# PSMs } \\
\text { detected }\end{array}$} & \multicolumn{2}{|l|}{ Saline } & \multicolumn{2}{|c|}{ MDMA low soc. } & \multicolumn{2}{|c|}{ WAY-100635 } & \multicolumn{2}{|c|}{ MDMA + WAY-100635 } & \multicolumn{2}{|c|}{ L-368899 } & \multicolumn{2}{|c|}{ MDMA + L-368899 } \\
\hline & & & & $\begin{array}{l}\text { Ratio to "MDMA } \\
\text { high soc." group }\end{array}$ & $\begin{array}{c}\text { Variability, } \\
{[\%]}\end{array}$ & $\begin{array}{l}\text { Ratio to "MDMA } \\
\text { high soc." group }\end{array}$ & $\begin{array}{c}\text { Variability, } \\
\text { [\%] }\end{array}$ & $\begin{array}{l}\text { Ratio to "MDMA } \\
\text { high soc." group }\end{array}$ & $\begin{array}{c}\text { Variability, } \\
{[\%]}\end{array}$ & $\begin{array}{l}\text { Ratio to "MDMA } \\
\text { high soc." group }\end{array}$ & $\begin{array}{c}\text { Variability, } \\
{[\%]}\end{array}$ & $\begin{array}{l}\text { Ratio to "MDMA } \\
\text { high soc." group }\end{array}$ & $\begin{array}{c}\text { Variability, } \\
\text { [\%] }\end{array}$ & $\begin{array}{l}\text { Ratio to "MDMA } \\
\text { high soc." group }\end{array}$ & $\begin{array}{c}\text { Variability, } \\
{[\%]}\end{array}$ \\
\hline Q61656 & $D d \times 5$ & 228 & 13 & $0.85 *$ & 4.8 & 0.79* & 10.0 & $0.84 *$ & 1.6 & $0.76 *$ & 4.8 & 0.88* & 4.6 & 0.94* & 3.3 \\
\hline Q9R1T4 & Sept6 & 127 & 7 & $0.84 *$ & 4.7 & $0.80 *$ & 5.5 & 0.90 & 8.5 & $0.76^{*}$ & 7.8 & 0.85 & 12.2 & 0.83 & 11.1 \\
\hline Q9JLB0 & Mpp6 & 119 & 4 & $0.84 *$ & 7.3 & $0.77 *$ & 10.4 & $0.77 *$ & 9.7 & $0.79 *$ & 7.1 & $0.80 *$ & 0.4 & $0.75 *$ & 0.0 \\
\hline P28738 & Kif5c & 204 & 9 & $0.84 *$ & 2.8 & $0.89 *$ & 2.7 & 0.86 & 16.4 & $0.70^{*}$ & 8.2 & 0.95 & 4.7 & 0.97 & 2.1 \\
\hline P49615 & Cdk5 & 42 & 2 & $0.82^{*}$ & 1.7 & $0.82^{*}$ & 1.2 & $0.85 *$ & 2.5 & $0.72 *$ & 6.1 & $0.92^{*}$ & 0.9 & 1.04 & 3.9 \\
\hline Q62188 & Dpys/3 & 136 & 6 & $0.82 *$ & 1.6 & $0.81 *$ & 0.4 & $0.77 *$ & 0.2 & $0.67 *$ & 13.5 & $0.84 *$ & 4.5 & $0.89 *$ & 8.1 \\
\hline Q62095 & $D d x 3 y$ & 102 & 7 & $0.81 *$ & 7.9 & $0.81 *$ & 14.5 & $0.80 *$ & 4.0 & $0.70 *$ & 5.4 & $0.81 *$ & 4.3 & $0.81 *$ & 10.1 \\
\hline Q9Z2Q6 & Sept5 & 36 & 2 & $0.81^{*}$ & 3.7 & $0.71^{*}$ & 4.7 & 0.87 & 9.2 & $0.72 *$ & 0.6 & 0.94 & 23.2 & 1.05 & 19.9 \\
\hline P60122 & Ruvbl1 & 105 & 4 & $0.80 *$ & 9.1 & $0.74 *$ & 0.7 & $0.82 *$ & 9.8 & $0.69 *$ & 20.3 & $0.89 *$ & 1.9 & 0.89 & 18.8 \\
\hline P54071 & Idh2 & 104 & 4 & $0.80 *$ & 5.3 & $0.69 *$ & 8.3 & $0.77 *$ & 3.1 & $0.69 *$ & 3.4 & $0.79 *$ & 7.0 & $0.87 *$ & 10.0 \\
\hline Q6PFD5 & Dlgap3 & 109 & 3 & $0.79 *$ & 10.7 & 0.86 & 27.0 & $0.82^{*}$ & 3.8 & $0.78^{*}$ & 11.9 & $0.98^{*}$ & 1.0 & $1.09 *$ & 1.0 \\
\hline Q4ACU6 & Shank3 & 64 & 3 & $0.77^{*}$ & 3.8 & $0.83^{*}$ & 3.7 & $0.76^{*}$ & 1.2 & $0.74 *$ & 16.1 & 0.87 & 10.8 & 0.96 & 12.7 \\
\hline Q9R0X4 & Acot9 & 48 & 3 & $0.77^{*}$ & 5.4 & $0.93 *$ & 2.5 & $0.79 *$ & 9.7 & $0.68^{*}$ & 10.7 & 1.06 & 35.9 & 1.01 & 7.7 \\
\hline O35098 & Dpys/4 & 84 & 4 & $0.76^{*}$ & 7.6 & 0.81 & 20.3 & $0.81^{*}$ & 6.9 & $0.69 *$ & 7.0 & $0.90^{*}$ & 5.1 & 0.96 & 4.8 \\
\hline Q9CZW5 & Tomm70a & 34 & 2 & $0.76^{*}$ & 0.7 & $0.79 *$ & 10.1 & $0.86 *$ & 6.8 & 0.83 & 18.6 & 0.92 & 14.7 & $0.93^{*}$ & 4.7 \\
\hline Q8CBE3 & Wdr37 & 62 & 3 & $0.72 *$ & 6.2 & $0.77 *$ & 12.4 & $0.81 *$ & 3.1 & $0.66 *$ & 10.5 & $0.87 *$ & 2.6 & 0.96 & 8.4 \\
\hline Q61553 & FsCn1 & 63 & 3 & $0.68^{*}$ & 0.4 & $0.82 *$ & 5.1 & $0.90 *$ & 3.3 & $0.69 *$ & 8.5 & 1.11 & 7.6 & $1.27 *$ & 3.8 \\
\hline
\end{tabular}

Data presented as relative proteins abundances, significantly different values are marked with * (confidence level 0.05 ).

Proteins with the highest correlation between their abundance and prosocial behavior are shown in bold. 
Tab. S2 Hippocampus: Proteins differently expressed in "Saline" and at least three other groups vs. "MDMA high sociability" group.

\begin{tabular}{|c|c|c|c|c|c|c|c|c|c|c|c|c|c|c|c|}
\hline \multirow[b]{2}{*}{$\begin{array}{c}\text { UniProt } \\
\text { Accession }\end{array}$} & \multirow[b]{2}{*}{ Gene name } & \multirow[b]{2}{*}{$\begin{array}{l}\text { Mascot } \\
\text { Score }\end{array}$} & \multirow[b]{2}{*}{$\begin{array}{l}\text { \# PSMs } \\
\text { detected }\end{array}$} & \multicolumn{2}{|l|}{ Saline } & \multicolumn{2}{|c|}{ MDMA low soc. } & \multicolumn{2}{|c|}{ WAY-100635 } & \multicolumn{2}{|c|}{ MDMA + WAY-100635 } & \multicolumn{2}{|c|}{ L-368899 } & \multicolumn{2}{|c|}{ MDMA + L-368899 } \\
\hline & & & & $\begin{array}{l}\text { Ratio to "MDMA } \\
\text { high soc." group }\end{array}$ & $\begin{array}{c}\text { Variability, } \\
{[\%]}\end{array}$ & $\begin{array}{l}\text { Ratio to "MDMA } \\
\text { high soc." group }\end{array}$ & $\begin{array}{c}\text { Variability, } \\
{[\%]}\end{array}$ & $\begin{array}{l}\text { Ratio to "MDMA } \\
\text { high soc." group }\end{array}$ & $\begin{array}{c}\text { Variability, } \\
{[\%]}\end{array}$ & $\begin{array}{l}\text { Ratio to "MDMA } \\
\text { high soc." group }\end{array}$ & $\begin{array}{c}\text { Variability, } \\
{[\%]}\end{array}$ & $\begin{array}{l}\text { Ratio to "MDMA } \\
\text { high soc." group }\end{array}$ & $\begin{array}{c}\text { Variability, } \\
{[\%]}\end{array}$ & $\begin{array}{l}\text { Ratio to "MDMA } \\
\text { high soc." group }\end{array}$ & $\begin{array}{c}\text { Variability, } \\
{[\%]}\end{array}$ \\
\hline P27546 & Mtap4 & 45 & 3 & $1.56 *$ & 3.7 & $1.35 *$ & 6.0 & $1.28 *$ & 4.1 & $1.75 *$ & 3.4 & $1.26 *$ & 6.1 & $1.27 *$ & 8.4 \\
\hline Q9QYG0 & Ndrg2 & 125 & 6 & $1.52 *$ & 17.2 & $1.31 *$ & 8.5 & $1.33 *$ & 15.6 & $1.60 *$ & 5.1 & $1.26 *$ & 9.4 & 1.10 & 18.6 \\
\hline Q8VBV7 & Cops8 & 35 & 2 & $1.51 *$ & 5.7 & $1.49 *$ & 1.7 & $1.49 *$ & 6.3 & 2.29* & 2.3 & $1.31 *$ & 4.5 & $1.13 *$ & 1.0 \\
\hline Q9Z2U0 & Psma7 & 57 & 3 & $1.29 *$ & 7.0 & 1.05 & 4.9 & $1.21^{*}$ & 4.4 & $1.23 *$ & 0.9 & $1.18^{*}$ & 0.3 & $1.16^{*}$ & 4.3 \\
\hline P97371 & Psme1 & 61 & 4 & $1.29 *$ & 7.1 & $1.25 *$ & 5.5 & $1.25 *$ & 10.5 & $1.75 *$ & 26.0 & $1.26 *$ & 3.4 & 1.18* & 0.5 \\
\hline Q71M36 & Cspg5 & 45 & 3 & $1.28 *$ & 5.4 & $1.32^{*}$ & 0.7 & $1.33 *$ & 1.3 & $1.93 *$ & 5.1 & $1.09 *$ & 3.8 & $1.11 *$ & 3.5 \\
\hline Q9JL62 & Gltp & 85 & 5 & $1.27 *$ & 10.3 & $1.32 *$ & 3.3 & $1.22 *$ & 1.5 & $1.72 *$ & 10.6 & 1.05 & 16.2 & 1.00 & 9.6 \\
\hline Q9JKK7 & Tmod2 & 116 & 6 & $1.25^{*}$ & 10.2 & $1.32 *$ & 2.5 & $1.26^{*}$ & 1.1 & $1.43 *$ & 3.9 & $1.26^{*}$ & 2.8 & 1.12 & 11.9 \\
\hline Q06138 & Cab39 & 78 & 4 & $1.25 *$ & 0.2 & $1.12^{*}$ & 1.5 & $1.29 *$ & 7.7 & $1.22 *$ & 5.8 & $1.36 *$ & 3.1 & $1.45 *$ & 1.2 \\
\hline Q8R395 & Commd5 & 37 & 2 & $1.24 *$ & 1.3 & $1.34 *$ & 10.9 & $1.13^{*}$ & 2.5 & $1.38^{*}$ & 4.2 & 1.00 & 2.0 & 0.86 & 15.3 \\
\hline P47802 & $M t x 1$ & 48 & 2 & $1.24 *$ & 7.8 & $1.26 *$ & 5.5 & $1.33^{*}$ & 4.3 & $1.47^{*}$ & 1.4 & $1.29 *$ & 2.3 & $1.34 *$ & 3.2 \\
\hline Q9QZ23 & Nfu1 & 55 & 2 & $1.23^{*}$ & 3.9 & $1.15^{*}$ & 4.5 & $1.29 *$ & 1.7 & $1.66^{*}$ & 11.1 & $1.04 *$ & 1.8 & 0.90 & 10.2 \\
\hline Q62393 & Tpd52 & 71 & 3 & $1.23^{*}$ & 1.5 & $1.25^{*}$ & 1.6 & $1.29 *$ & 6.9 & $1.74 *$ & 3.9 & 1.04 & 2.9 & 0.94 & 10.5 \\
\hline Q63912 & Omg & 57 & 3 & $1.21^{*}$ & 2.3 & $1.36^{*}$ & 4.7 & $1.32 *$ & 1.5 & $1.96 *$ & 4.6 & 1.10 & 17.7 & 0.89 & 18.3 \\
\hline O55026 & Entpd2 & 64 & 3 & $1.21^{*}$ & 0.9 & $1.28^{*}$ & 5.3 & $1.25^{*}$ & 5.7 & $1.57^{*}$ & 1.6 & 0.99 & 1.3 & 1.01 & 10.8 \\
\hline P58771 & Tpm1 & 107 & 6 & $1.18 *$ & 2.9 & $1.30 *$ & 6.1 & $1.22 *$ & 7.3 & $1.47 *$ & 15.2 & $1.06 *$ & 4.6 & $1.03 *$ & 0.7 \\
\hline P15532 & Nme1 & 74 & 4 & $1.16^{*}$ & 0.4 & $1.23^{*}$ & 6.9 & $1.22 *$ & 3.5 & $1.60 *$ & 5.6 & $1.10^{*}$ & 2.4 & $0.94 *$ & 0.7 \\
\hline Q8VIM9 & Irgq & 37 & 2 & $1.13^{*}$ & 2.5 & 1.15 & 9.1 & $1.18^{*}$ & 0.6 & $1.68 *$ & 9.3 & $1.18^{*}$ & 1.4 & 1.04 & 2.7 \\
\hline Q91X97 & Ncald & 256 & 13 & $1.12^{*}$ & 2.8 & $1.11^{*}$ & 2.8 & $1.23^{*}$ & 8.8 & $1.39 *$ & 12.6 & 1.06 & 6.9 & 1.05 & 3.6 \\
\hline Q8C419 & Gpr158 & 72 & 4 & $1.12^{*}$ & 4.7 & $1.24 *$ & 0.2 & $1.17^{*}$ & 3.4 & $1.68^{*}$ & 1.9 & 1.00 & 6.1 & 1.00 & 17.9 \\
\hline P17809 & Slc2a1 & 39 & 4 & 1.11* & 3.3 & $1.44^{*}$ & 1.9 & $1.31 *$ & 6.4 & $1.27 *$ & 5.9 & $1.37 *$ & 3.6 & $1.80 *$ & 8.1 \\
\hline Q91VR8 & Brk1 & 41 & 3 & $1.09 *$ & 1.0 & 1.19* & 2.3 & $1.33 *$ & 8.4 & $1.76 *$ & 4.3 & $1.41 *$ & 4.7 & $1.22^{*}$ & 4.4 \\
\hline Q9Z1S5 & Sept3 & 49 & 4 & $0.91^{*}$ & 2.1 & $0.83^{*}$ & 7.3 & 0.99 & 0.2 & $1.04 *$ & 1.9 & 0.90 & 7.6 & $0.88^{*}$ & 4.0 \\
\hline Q9CPX6 & $\operatorname{Atg} 3$ & 54 & 3 & $0.90^{*}$ & 1.2 & $0.85^{*}$ & 6.8 & 0.87 & 7.7 & $0.87 *$ & 1.9 & 0.99 & 2.4 & $0.85^{*}$ & 5.4 \\
\hline Q9JII6 & Akr1a1 & 42 & 3 & $0.89 *$ & 2.7 & $0.75^{*}$ & 3.9 & $0.78^{*}$ & 2.2 & 0.83 & 19.9 & $0.95 *$ & 1.5 & $0.83^{*}$ & 7.5 \\
\hline P26638 & Sars & 49 & 3 & $0.88^{*}$ & 6.8 & $0.83^{*}$ & 5.3 & $0.87^{*}$ & 3.3 & $0.71^{*}$ & 4.0 & $0.90 *$ & 2.9 & 0.98 & 1.8 \\
\hline Q9D1G5 & Lrrc57 & 40 & 2 & $0.88^{*}$ & 3.6 & $0.81^{*}$ & 2.4 & $0.93^{*}$ & 3.7 & 0.95 & 6.6 & 0.91 & 4.9 & $0.87^{*}$ & 1.5 \\
\hline Q8BGQ7 & Aars & 189 & 6 & $0.87 *$ & 5.7 & $0.87^{*}$ & 6.6 & $0.86 *$ & 3.4 & $0.69 *$ & 16.3 & 0.97 & 7.1 & 0.98 & 14.6 \\
\hline Q9CZ30 & Ola1 & 52 & 4 & $0.86^{*}$ & 7.5 & $0.76^{*}$ & 3.8 & $0.85^{*}$ & 3.8 & $0.78^{*}$ & 3.2 & 0.85 & 8.5 & 0.86 & 4.4 \\
\hline Q9CWS0 & Ddah1 & 59 & 2 & $0.85^{*}$ & 0.3 & 0.92 & 7.4 & $0.90 *$ & 1.7 & $0.95 *$ & 1.4 & $0.70^{*}$ & 2.3 & $0.73^{*}$ & 2.1 \\
\hline
\end{tabular}


Tab. S2 Hippocampus: Proteins differently expressed in "Saline" and at least three other groups vs. "MDMA high sociability" group.

\begin{tabular}{|c|c|c|c|c|c|c|c|c|c|c|c|c|c|c|c|}
\hline \multirow[b]{2}{*}{$\begin{array}{c}\text { UniProt } \\
\text { Accession }\end{array}$} & \multirow[b]{2}{*}{ Gene name } & \multirow[b]{2}{*}{$\begin{array}{l}\text { Mascot } \\
\text { Score }\end{array}$} & \multirow[b]{2}{*}{$\begin{array}{l}\text { \# PSMs } \\
\text { detected }\end{array}$} & \multicolumn{2}{|l|}{ Saline } & \multicolumn{2}{|c|}{ MDMA low soc. } & \multicolumn{2}{|c|}{ WAY-100635 } & \multicolumn{2}{|c|}{ MDMA + WAY-100635 } & \multicolumn{2}{|c|}{ L-368899 } & \multicolumn{2}{|c|}{ MDMA + L-368899 } \\
\hline & & & & $\begin{array}{l}\text { Ratio to "MDMA } \\
\text { high soc." group }\end{array}$ & $\begin{array}{c}\text { Variability, } \\
{[\%]}\end{array}$ & $\begin{array}{l}\text { Ratio to "MDMA } \\
\text { high soc." group }\end{array}$ & $\begin{array}{c}\text { Variability, } \\
\text { [\%] }\end{array}$ & $\begin{array}{l}\text { Ratio to "MDMA } \\
\text { high soc." group }\end{array}$ & $\begin{array}{c}\text { Variability, } \\
{[\%]}\end{array}$ & $\begin{array}{l}\text { Ratio to "MDMA } \\
\text { high soc." group }\end{array}$ & $\begin{array}{c}\text { Variability, } \\
{[\%]}\end{array}$ & $\begin{array}{l}\text { Ratio to "MDMA } \\
\text { high soc." group }\end{array}$ & $\begin{array}{c}\text { Variability, } \\
\text { [\%] }\end{array}$ & $\begin{array}{l}\text { Ratio to "MDMA } \\
\text { high soc." group }\end{array}$ & $\begin{array}{c}\text { Variability, } \\
{[\%]}\end{array}$ \\
\hline Q61656 & $D d \times 5$ & 228 & 13 & $0.85 *$ & 4.8 & 0.79* & 10.0 & $0.84 *$ & 1.6 & $0.76 *$ & 4.8 & 0.88* & 4.6 & 0.94* & 3.3 \\
\hline Q9R1T4 & Sept6 & 127 & 7 & $0.84 *$ & 4.7 & $0.80 *$ & 5.5 & 0.90 & 8.5 & $0.76^{*}$ & 7.8 & 0.85 & 12.2 & 0.83 & 11.1 \\
\hline Q9JLB0 & Mpp6 & 119 & 4 & $0.84 *$ & 7.3 & $0.77 *$ & 10.4 & $0.77 *$ & 9.7 & $0.79 *$ & 7.1 & $0.80 *$ & 0.4 & $0.75 *$ & 0.0 \\
\hline P28738 & Kif5c & 204 & 9 & $0.84 *$ & 2.8 & $0.89 *$ & 2.7 & 0.86 & 16.4 & $0.70^{*}$ & 8.2 & 0.95 & 4.7 & 0.97 & 2.1 \\
\hline P49615 & Cdk5 & 42 & 2 & $0.82^{*}$ & 1.7 & $0.82^{*}$ & 1.2 & $0.85 *$ & 2.5 & $0.72 *$ & 6.1 & $0.92^{*}$ & 0.9 & 1.04 & 3.9 \\
\hline Q62188 & Dpys/3 & 136 & 6 & $0.82 *$ & 1.6 & $0.81 *$ & 0.4 & $0.77 *$ & 0.2 & $0.67 *$ & 13.5 & $0.84 *$ & 4.5 & $0.89 *$ & 8.1 \\
\hline Q62095 & $D d x 3 y$ & 102 & 7 & $0.81 *$ & 7.9 & $0.81 *$ & 14.5 & $0.80 *$ & 4.0 & $0.70 *$ & 5.4 & $0.81 *$ & 4.3 & $0.81 *$ & 10.1 \\
\hline Q9Z2Q6 & Sept5 & 36 & 2 & $0.81^{*}$ & 3.7 & $0.71^{*}$ & 4.7 & 0.87 & 9.2 & $0.72 *$ & 0.6 & 0.94 & 23.2 & 1.05 & 19.9 \\
\hline P60122 & Ruvbl1 & 105 & 4 & $0.80 *$ & 9.1 & $0.74 *$ & 0.7 & $0.82 *$ & 9.8 & $0.69 *$ & 20.3 & $0.89 *$ & 1.9 & 0.89 & 18.8 \\
\hline P54071 & Idh2 & 104 & 4 & $0.80 *$ & 5.3 & $0.69 *$ & 8.3 & $0.77 *$ & 3.1 & $0.69 *$ & 3.4 & $0.79 *$ & 7.0 & $0.87 *$ & 10.0 \\
\hline Q6PFD5 & Dlgap3 & 109 & 3 & $0.79 *$ & 10.7 & 0.86 & 27.0 & $0.82^{*}$ & 3.8 & $0.78^{*}$ & 11.9 & $0.98^{*}$ & 1.0 & $1.09 *$ & 1.0 \\
\hline Q4ACU6 & Shank3 & 64 & 3 & $0.77^{*}$ & 3.8 & $0.83^{*}$ & 3.7 & $0.76^{*}$ & 1.2 & $0.74 *$ & 16.1 & 0.87 & 10.8 & 0.96 & 12.7 \\
\hline Q9R0X4 & Acot9 & 48 & 3 & $0.77^{*}$ & 5.4 & $0.93 *$ & 2.5 & $0.79 *$ & 9.7 & $0.68^{*}$ & 10.7 & 1.06 & 35.9 & 1.01 & 7.7 \\
\hline O35098 & Dpys/4 & 84 & 4 & $0.76^{*}$ & 7.6 & 0.81 & 20.3 & $0.81^{*}$ & 6.9 & $0.69 *$ & 7.0 & $0.90^{*}$ & 5.1 & 0.96 & 4.8 \\
\hline Q9CZW5 & Tomm70a & 34 & 2 & $0.76^{*}$ & 0.7 & $0.79 *$ & 10.1 & $0.86 *$ & 6.8 & 0.83 & 18.6 & 0.92 & 14.7 & $0.93^{*}$ & 4.7 \\
\hline Q8CBE3 & Wdr37 & 62 & 3 & $0.72 *$ & 6.2 & $0.77 *$ & 12.4 & $0.81 *$ & 3.1 & $0.66 *$ & 10.5 & $0.87 *$ & 2.6 & 0.96 & 8.4 \\
\hline Q61553 & FsCn1 & 63 & 3 & $0.68^{*}$ & 0.4 & $0.82 *$ & 5.1 & $0.90 *$ & 3.3 & $0.69 *$ & 8.5 & 1.11 & 7.6 & $1.27 *$ & 3.8 \\
\hline
\end{tabular}

Data presented as relative proteins abundances, significantly different values are marked with * (confidence level 0.05 ).

Proteins with the highest correlation between their abundance and prosocial behavior are shown in bold. 
Tab. S3 Amygdala: Proteins differently expressed in "Saline" and at least three other groups vs. "MDMA high sociability" group.

\begin{tabular}{|c|c|c|c|c|c|c|c|c|c|c|c|c|c|c|c|}
\hline \multirow[b]{2}{*}{$\begin{array}{c}\text { UniProt } \\
\text { Accession }\end{array}$} & \multirow[b]{2}{*}{ Gene name } & \multirow[b]{2}{*}{$\begin{array}{l}\text { Mascot } \\
\text { Score }\end{array}$} & \multirow[b]{2}{*}{$\begin{array}{l}\text { \# PSMs } \\
\text { detected }\end{array}$} & \multicolumn{2}{|c|}{ Saline } & \multicolumn{2}{|c|}{ MDMA low soc. } & \multicolumn{2}{|c|}{ WAY-100635 } & \multicolumn{2}{|c|}{ MDMA + WAY-100635 } & \multicolumn{2}{|c|}{ L-368899 } & \multicolumn{2}{|c|}{ MDMA + L-368899 } \\
\hline & & & & $\begin{array}{l}\text { Ratio to "MDMA } \\
\text { high soc." group }\end{array}$ & $\begin{array}{c}\text { Variability, } \\
{[\%]}\end{array}$ & $\begin{array}{l}\text { Ratio to "MDMA } \\
\text { high soc." group }\end{array}$ & $\begin{array}{c}\text { Variability, } \\
{[\%]}\end{array}$ & $\begin{array}{l}\text { Ratio to "MDMA } \\
\text { high soc." group }\end{array}$ & $\begin{array}{c}\text { Variability, } \\
{[\%]}\end{array}$ & $\begin{array}{l}\text { Ratio to "MDMA } \\
\text { high soc." group }\end{array}$ & $\begin{array}{c}\text { Variability, } \\
{[\%]}\end{array}$ & $\begin{array}{l}\text { Ratio to "MDMA } \\
\text { high soc." group }\end{array}$ & $\begin{array}{c}\text { Variability, } \\
{[\%]}\end{array}$ & $\begin{array}{l}\text { Ratio to "MDMA } \\
\text { high soc." group }\end{array}$ & $\begin{array}{c}\text { Variability, } \\
{[\%]}\end{array}$ \\
\hline Q2PFD7 & Psd3 & 58 & 3 & $1.44 *$ & 10.0 & $1.19 *$ & 6.3 & $1.57 *$ & 7.3 & $1.21^{*}$ & 6.5 & 0.77 & 15.3 & $1.54 *$ & 0.6 \\
\hline Q99L43 & Cds2 & 75 & 5 & $1.20 *$ & 3.4 & $1.24 *$ & 7.1 & $1.08 *$ & 2.2 & $1.18 *$ & 1.1 & $1.28 *$ & 1.7 & $1.29 *$ & 8.4 \\
\hline P48453 & Ppp3cb & 96 & 10 & $1.19 *$ & 1.6 & $1.16^{*}$ & 3.6 & 1.10 & 8.0 & $1.10^{*}$ & 1.3 & 1.08 & 13.2 & 1.15 & 11.6 \\
\hline P23819 & Gria2 & 107 & 8 & $1.18^{*}$ & 11.3 & $1.31 *$ & 14.4 & $1.27 *$ & 13.6 & 1.22 & 10.1 & 1.17 & 13.9 & $1.35 *$ & 13.7 \\
\hline P99027 & Rplp2 & 54 & 5 & $1.16^{*}$ & 5.2 & $1.21^{*}$ & 5.8 & 0.95 & 4.6 & $1.26 *$ & 4.7 & $1.34 *$ & 1.6 & $1.03 *$ & 0.4 \\
\hline 008599 & Stxbp1 & 691 & 69 & $0.94 *$ & 0.1 & $0.82 *$ & 2.8 & $0.88^{*}$ & 0.7 & $0.84 *$ & 8.2 & $0.79 *$ & 3.2 & $0.82^{*}$ & 0.1 \\
\hline Q8CAY6 & Acat2 & 52 & 6 & $0.93 *$ & 2.3 & $0.86^{*}$ & 3.2 & 0.94 & 7.5 & $0.84 *$ & 3.1 & 0.97 & 4.6 & 0.95 & 11.0 \\
\hline Q8BVI4 & $Q d p r$ & 117 & 9 & $0.92 *$ & 6.7 & $0.81^{*}$ & 4.2 & $0.89 *$ & 5.4 & $0.83 *$ & 8.6 & 0.68 & 44.8 & $0.80^{*}$ & 5.6 \\
\hline Q8K1Z0 & $\operatorname{Coq} 9$ & 41 & 4 & $0.91 *$ & 4.1 & $0.88^{*}$ & 0.1 & 0.88 & 10.3 & $0.91 *$ & 4.3 & $0.89 *$ & 4.9 & $0.96 *$ & 1.4 \\
\hline P27546 & Mtap4 & 57 & 5 & $0.87 *$ & 6.9 & $0.86 *$ & 3.3 & $0.96 *$ & 1.7 & $0.97 *$ & 2.4 & $0.87 *$ & 5.2 & $0.89 *$ & 0.1 \\
\hline Q61033 & Tmpo & 28 & 3 & $0.86^{*}$ & 6.3 & $0.80^{*}$ & 7.7 & 1.01 & 25.8 & $0.90 *$ & 0.9 & $0.90 *$ & 4.2 & $0.85^{*}$ & 1.8 \\
\hline Q9JM63 & Kcnj10 & 53 & 8 & $0.81^{*}$ & 10.3 & $0.82 *$ & 9.7 & $0.82 *$ & 6.2 & $0.93 *$ & 2.9 & 1.20 & 8.7 & 1.04 & 6.1 \\
\hline Q80WM4 & Hapln4 & 76 & 4 & $0.80 *$ & 8.2 & $0.87 *$ & 3.1 & 0.96 & 8.6 & $0.80 *$ & 11.8 & $0.88^{*}$ & 2.1 & $0.78^{*}$ & 1.4 \\
\hline Q6P9J5 & Kank4 & 58 & 2 & $0.78^{*}$ & 6.0 & 0.87 & 31.3 & $0.78^{*}$ & 12.6 & 0.90 & 7.7 & $0.85 *$ & 1.4 & $0.69 *$ & 0.3 \\
\hline P11531 & Dmd & 93 & 6 & $0.74 *$ & 8.3 & 0.97 & 17.1 & $0.81 *$ & 0.7 & 0.94 & 7.0 & $0.89 *$ & 0.7 & $0.49 *$ & 10.6 \\
\hline P62141 & Ppp1cb & 141 & 19 & $0.71 *$ & 3.1 & $0.88^{*}$ & 0.3 & 0.89 & 16.8 & 0.95 & 6.5 & 0.84 & 6.2 & $0.87 *$ & 3.1 \\
\hline
\end{tabular}

Data presented as relative proteins abundances, significantly different values are marked with * (confidence level 0.05 ).

Proteins with the highest correlation between their abundance and prosocial behavior are shown in bold. 
Tab. S4 Cortex: Proteins differently expressed in "MDMA low sociability" vs. "MDMA high sociability" group.

\begin{tabular}{|c|c|c|c|c|c|c|c|}
\hline \multirow{2}{*}{$\begin{array}{l}\text { UniProt } \\
\text { Accession }\end{array}$} & \multirow[b]{2}{*}{ Gene name } & \multirow[b]{2}{*}{$\begin{array}{l}\text { Mascot } \\
\text { Score }\end{array}$} & \multirow[b]{2}{*}{$\begin{array}{l}\text { \# PSMs } \\
\text { detected }\end{array}$} & \multicolumn{2}{|c|}{ MDMA low sociability } & \multicolumn{2}{|l|}{ Saline } \\
\hline & & & & $\begin{array}{l}\text { Ratio to "MDMA high } \\
\text { sociability" group }\end{array}$ & $\begin{array}{c}\text { Variability, } \\
{[\%]}\end{array}$ & $\begin{array}{l}\text { Ratio to "MDMA high } \\
\text { sociability" group }\end{array}$ & $\begin{array}{c}\text { Variability, } \\
{[\%]}\end{array}$ \\
\hline P08228 & Sod1 & 74 & 2 & $1.73 *$ & 0.6 & 0.99 & 18.5 \\
\hline P47955 & Rplp1 & 83 & 5 & $1.66^{*}$ & 12.8 & 1.04 & 21.2 \\
\hline Q9DB34 & Chmp2a & 101 & 5 & $1.58 *$ & 17.3 & $1.56^{*}$ & 16.4 \\
\hline 035465 & $F k b p 8$ & 46 & 3 & $1.49 *$ & 11.1 & $1.18^{*}$ & 2.4 \\
\hline Q8K354 & $C b r 3$ & 56 & 4 & $1.46 *$ & 12.0 & 1.03 & 4.1 \\
\hline P51859 & $H d g f$ & 32 & 2 & $1.45^{*}$ & 1.8 & 1.06 & 17.9 \\
\hline Q9Z1L5 & Cacna2d3 & 32 & 2 & $1.41^{*}$ & 8.6 & 1.05 & 6.3 \\
\hline Q61597 & Crygc & 29 & 2 & $1.39 *$ & 13.9 & 1.02 & 5.1 \\
\hline P12787 & Cox5a & 66 & 4 & $1.33^{*}$ & 1.2 & 0.97 & 7.5 \\
\hline P23819 & Gria2 & 130 & 10 & $1.31 *$ & 9.2 & 1.11 & 12.3 \\
\hline Q8C5H8 & Nadkd1 & 42 & 3 & $1.30 *$ & 3.4 & 1.00 & 0.1 \\
\hline Q9D0I9 & Rars & 33 & 3 & $1.29 *$ & 11.2 & $1.07^{*}$ & 2.5 \\
\hline P51660 & Hsd17b4 & 37 & 3 & $1.28 *$ & 8.4 & 1.04 & 5.4 \\
\hline B1AXH1 & Nhs/2 & 33 & 2 & $1.27 *$ & 7.1 & 1.09 & 4.8 \\
\hline Q9EPR5 & Sorcs2 & 25 & 2 & $1.27 *$ & 1.0 & 1.06 & 10.3 \\
\hline B1AXP6 & Tomm5 & 42 & 3 & $1.26 *$ & 0.6 & 0.99 & 12.9 \\
\hline Q9QXA5 & Lsm4 & 41 & 2 & $1.26^{*}$ & 10.1 & 1.09 & 6.8 \\
\hline Q9Z204 & Hnrnpc & 35 & 3 & $1.26^{*}$ & 5.3 & 1.06 & 27.7 \\
\hline Q9R1J0 & Nsdhl & 38 & 2 & $1.26 *$ & 5.1 & 1.19 & 10.7 \\
\hline Q9QZE5 & Copg & 22 & 2 & $1.25^{*}$ & 8.2 & 1.04 & 7.7 \\
\hline Q8R5J9 & Arl6ip5 & 50 & 2 & $1.25 *$ & 1.0 & 1.15 & 10.3 \\
\hline Q9QXS6 & $D b n 1$ & 16 & 2 & $1.25^{*}$ & 7.7 & 1.15 & 9.4 \\
\hline P39054 & Dnm2 & 218 & 19 & $1.25^{*}$ & 6.1 & $1.09 *$ & 2.6 \\
\hline P32037 & Slc2a3 & 36 & 5 & $1.25^{*}$ & 3.1 & 1.08 & 16.8 \\
\hline Q791V5 & Mtch2 & 49 & 3 & $1.24 *$ & 9.7 & 1.03 & 16.0 \\
\hline 035344 & Kpna3 & 76 & 5 & $1.24 *$ & 8.4 & 1.02 & 5.4 \\
\hline Q9QXV0 & Pcsk1n & 29 & 2 & $1.24 *$ & 8.0 & 0.94 & 7.1 \\
\hline Q8R464 & Cadm4 & 28 & 2 & $1.23 *$ & 1.0 & 1.01 & 1.2 \\
\hline A2CG49 & Kalrn & 29 & 3 & $1.23 *$ & 6.2 & 0.98 & 22.0 \\
\hline Q8VDM4 & Psmd2 & 38 & 3 & $1.23 *$ & 8.5 & 1.03 & 13.9 \\
\hline Q80TL0 & Ppm1e & 31 & 2 & $1.23 *$ & 0.7 & 0.87 & 21.9 \\
\hline Q5EBJ4 & Ermn & 70 & 2 & $1.22 *$ & 1.1 & $1.28^{*}$ & 9.5 \\
\hline Q8VDQ8 & Sirt2 & 126 & 11 & $1.22 *$ & 9.2 & 1.01 & 8.2 \\
\hline Q9CRY7 & $G d p d 1$ & 38 & 3 & $1.22 *$ & 6.9 & 0.96 & 5.3 \\
\hline Q8BPM2 & Map4k5 & 32 & 3 & $1.22 *$ & 4.0 & $0.91^{*}$ & 0.7 \\
\hline Q7TME0 & Lppr4 & 35 & 5 & $1.21^{*}$ & 6.7 & 0.96 & 11.2 \\
\hline P57776 & Eef1d & 51 & 3 & $1.21 *$ & 1.2 & 1.04 & 10.4 \\
\hline Q80Z10 & Astn2 & 30 & 2 & $1.20 *$ & 1.3 & 1.12 & 6.9 \\
\hline Q8VCN9 & Tbcc & 28 & 3 & $1.20 *$ & 2.5 & 1.00 & 2.0 \\
\hline Q8R5M0 & Gipc3 & 28 & 2 & $1.20 *$ & 0.9 & 1.07 & 10.9 \\
\hline Q00623 & Apoa1 & 230 & 17 & $1.18^{*}$ & 9.5 & 1.05 & 10.3 \\
\hline 055142 & Rpl35a & 30 & 2 & $1.18^{*}$ & 0.9 & 1.09 & 2.9 \\
\hline Q9D7H3 & Rtcd1 & 22 & 2 & $1.14 *$ & 3.5 & $1.16 *$ & 3.0 \\
\hline P62823 & Rab3c & 76 & 12 & $0.80 *$ & 10.5 & $0.87^{*}$ & 6.4 \\
\hline P10711 & Tcea1 & 28 & 2 & $0.79 *$ & 10.2 & 1.03 & 3.5 \\
\hline 070378 & Cox4nb & 49 & 3 & 0.79* & 11.7 & 0.98 & 3.7 \\
\hline Q80ZW2 & Them6 & 46 & 3 & $0.79 *$ & 5.9 & 1.01 & 8.2 \\
\hline P43274 & Hist1h1e & 115 & 10 & $0.78 *$ & 10.7 & 0.97 & 5.7 \\
\hline
\end{tabular}

Page 1 from 2 
Tab. S4 Cortex: Proteins differently expressed in "MDMA low sociability" vs. "MDMA high sociability" group.

\begin{tabular}{|c|c|c|c|c|c|c|c|}
\hline \multirow{2}{*}{$\begin{array}{l}\text { UniProt } \\
\text { Accession }\end{array}$} & \multirow[b]{2}{*}{ Gene name } & \multirow{2}{*}{$\begin{array}{l}\text { Mascot } \\
\text { Score }\end{array}$} & \multirow{2}{*}{$\begin{array}{l}\text { \# PSMs } \\
\text { detected }\end{array}$} & \multicolumn{2}{|c|}{ MDMA low sociability } & \multicolumn{2}{|l|}{ Saline } \\
\hline & & & & $\begin{array}{l}\text { Ratio to "MDMA high } \\
\text { sociability" group }\end{array}$ & $\begin{array}{c}\text { Variability, } \\
{[\%]}\end{array}$ & $\begin{array}{l}\text { Ratio to "MDMA high } \\
\text { sociability" group }\end{array}$ & $\begin{array}{c}\text { Variability, } \\
{[\%]}\end{array}$ \\
\hline Q8CFI5 & Pars2 & 29 & 2 & $0.78 *$ & 1.3 & 0.93 & 6.4 \\
\hline Q8BZ98 & Dnm3 & 254 & 27 & $0.77^{*}$ & 4.3 & 1.04 & 3.3 \\
\hline Q91WK5 & Gcsh & 44 & 2 & $0.76 *$ & 5.3 & 0.91 & 5.8 \\
\hline Q9CY58 & Serbp1 & 78 & 2 & $0.75^{*}$ & 5.0 & 0.99 & 9.5 \\
\hline Q8BSF4 & Pisd & 23 & 3 & $0.75^{*}$ & 0.8 & 1.04 & 17.0 \\
\hline P01831 & Thy1 & 52 & 5 & $0.75^{*}$ & 2.8 & 1.02 & 7.9 \\
\hline Q9D0T1 & Nhp2l1 & 30 & 2 & $0.75^{*}$ & 6.0 & 0.94* & 1.3 \\
\hline Q78IK2 & Usmg5 & 76 & 2 & $0.75^{*}$ & 7.3 & 0.93* & 3.5 \\
\hline Q99JI6 & Rap1b & 49 & 4 & $0.75^{*}$ & 8.5 & 0.85 & 10.9 \\
\hline P12815 & Pdcd6 & 69 & 6 & $0.74 *$ & 13.3 & 1.06 & 13.4 \\
\hline Q8VEH3 & Arl8a & 75 & 4 & $0.74 *$ & 5.3 & 0.98 & 3.6 \\
\hline P46097 & Syt2 & 110 & 8 & $0.74 *$ & 5.7 & $1.03 *$ & 0.6 \\
\hline Q3U2V3 & Nudt18 & 30 & 2 & $0.74 *$ & 4.5 & 1.10 & 4.7 \\
\hline P62746 & Rhob & 83 & 7 & $0.73 *$ & 5.0 & $0.89 *$ & 1.2 \\
\hline P84096 & Rhog & 86 & 8 & $0.73 *$ & 5.2 & 0.94 & 4.0 \\
\hline Q9CQC6 & $B z w 1$ & 63 & 4 & $0.71 *$ & 4.4 & $0.91 *$ & 4.0 \\
\hline Q8BH95 & Echs1 & 65 & 2 & $0.71 *$ & 4.2 & 1.30 & 57.1 \\
\hline Q62283 & Tspan7 & 37 & 4 & $0.70 *$ & 11.9 & 1.09 & 8.6 \\
\hline Q9CWS0 & Ddah1 & 66 & 6 & $0.70 *$ & 19.6 & 0.99 & 13.5 \\
\hline P62743 & $A p 2 s 1$ & 47 & 4 & $0.70 *$ & 11.5 & 1.06 & 12.8 \\
\hline 008917 & Flot1 & 57 & 8 & $0.69 *$ & 18.3 & 1.00 & 5.0 \\
\hline P14115 & Rpl27a & 30 & 2 & $0.68 *$ & 6.1 & 0.93 & 7.6 \\
\hline Q91WK2 & Eif3h & 25 & 2 & $0.68^{*}$ & 0.7 & $0.87 *$ & 0.5 \\
\hline Q8BP67 & Rp/24 & 63 & 3 & $0.67 *$ & 6.1 & $1.15^{*}$ & 0.8 \\
\hline 070305 & Atxn2 & 23 & 2 & $0.67 *$ & 7.9 & 0.99 & 3.9 \\
\hline P63046 & Sult4a1 & 43 & 3 & $0.65 *$ & 16.0 & $0.90 *$ & 2.4 \\
\hline P62849 & Rps24 & 34 & 2 & $0.61 *$ & 10.5 & 1.11 & 8.4 \\
\hline P10922 & H1fO & 29 & 2 & $0.60 *$ & 3.4 & 1.04 & 24.0 \\
\hline P21460 & Cst3 & 46 & 2 & $0.58 *$ & 14.7 & 1.07 & 3.8 \\
\hline Q8BYR5 & Cadps2 & 38 & 4 & $0.48^{*}$ & 6.1 & 0.97 & 10.2 \\
\hline Q91VR2 & Atp5c1 & 124 & 20 & $0.48^{*}$ & 50.0 & 0.97 & 10.0 \\
\hline P97315 & Csrp1 & 68 & 3 & $0.43 *$ & 15.9 & 0.93 & 10.2 \\
\hline
\end{tabular}

Data presented as relative proteins abundances

Significantly different values are marked with * (confidence level 0.05). 
Tab. S5 Hippocampus: Proteins differently expressed in "MDMA low sociability" vs. "MDMA high sociability" group

\begin{tabular}{|c|c|c|c|c|c|c|c|}
\hline \multirow{2}{*}{$\begin{array}{c}\text { UniProt } \\
\text { Accession }\end{array}$} & \multirow[b]{2}{*}{ Gene name } & \multirow{2}{*}{$\begin{array}{l}\text { Mascot } \\
\text { Score }\end{array}$} & \multirow{2}{*}{$\begin{array}{c}\text { \# PSMs } \\
\text { detected }\end{array}$} & \multicolumn{2}{|c|}{ MDMA low sociability } & \multicolumn{2}{|l|}{ Saline } \\
\hline & & & & $\begin{array}{l}\text { Ratio to "MDMA high } \\
\text { sociability" group }\end{array}$ & $\begin{array}{c}\text { Variability, } \\
{[\%]}\end{array}$ & $\begin{array}{l}\text { Ratio to "MDMA high } \\
\text { sociability" group }\end{array}$ & $\begin{array}{c}\text { Variability, } \\
{[\%]}\end{array}$ \\
\hline P26645 & Marcks & 54 & 2 & $1.95^{*}$ & 6.1 & $1.43 *$ & 5.8 \\
\hline P50153 & Gng4 & 20 & 4 & $1.66 *$ & 5.5 & $1.30 *$ & 0.3 \\
\hline 008677 & Kng1 & 28 & 2 & $1.53 *$ & 5.9 & $1.41 *$ & 2.0 \\
\hline Q08331 & Calb2 & 97 & 6 & $1.51^{*}$ & 14.6 & $1.42 *$ & 6.2 \\
\hline P31650 & Slc6a11 & 41 & 2 & 1.49* & 13.8 & 1.25 & 10.1 \\
\hline Q6ZQ18 & $E f r 3 b$ & 30 & 2 & $1.48^{*}$ & 5.5 & 0.99 & 9.8 \\
\hline Q00623 & Apoa1 & 66 & 2 & $1.47 *$ & 7.9 & $1.39 *$ & 8.4 \\
\hline Q9CYZ2 & $T p d 5212$ & 50 & 5 & $1.44 *$ & 13.5 & $1.35^{*}$ & 6.0 \\
\hline P62748 & Hpcal1 & 91 & 5 & $1.40 *$ & 12.2 & $1.40 *$ & 12.3 \\
\hline P19096 & Fasn & 36 & 3 & $1.39 *$ & 9.7 & 0.99 & 1.4 \\
\hline Q8K0T0 & Rtn1 & 39 & 5 & $1.38^{*}$ & 12.2 & 1.17 & 20.4 \\
\hline P19246 & Nefh & 122 & 8 & $1.37 *$ & 3.4 & $1.23 *$ & 7.9 \\
\hline P62761 & Vsnl1 & 314 & 17 & $1.36 *$ & 11.8 & $1.36 *$ & 12.6 \\
\hline Q6IRU5 & Cltb & 42 & 3 & $1.36^{*}$ & 3.4 & $1.22 *$ & 5.5 \\
\hline Q6PIC6 & Atp1a3 & 328 & 15 & $1.34 *$ & 7.5 & 1.02 & 8.7 \\
\hline Q920I9 & $W d r 7$ & 48 & 3 & $1.34 *$ & 9.8 & 0.94 & 23.1 \\
\hline P31648 & Slc6a1 & 32 & 2 & $1.33 *$ & 1.0 & 1.08 & 13.2 \\
\hline Q8C0M9 & Asrgl1 & 82 & 3 & 1.33* & 7.7 & 1.45 & 16.4 \\
\hline P09405 & $\mathrm{NCl}$ & 85 & 6 & $1.33 *$ & 10.4 & $1.23 *$ & 7.0 \\
\hline P60202 & Plp1 & 32 & 7 & $1.33 *$ & 17.5 & 0.86 & 17.3 \\
\hline Q8BPN8 & $D m x / 2$ & 76 & 5 & 1.33* & 1.4 & 0.97 & 13.3 \\
\hline Q8VCR7 & $A b h d 14 b$ & 30 & 4 & $1.32 *$ & 10.9 & 1.30 & 18.1 \\
\hline Q80TB8 & Vat1I & 51 & 3 & $1.32 *$ & 4.0 & 1.21 & 14.8 \\
\hline Q62425 & Ndufa4 & 43 & 2 & $1.30 *$ & 10.6 & $1.29 *$ & 11.5 \\
\hline Q9JHU4 & Dync1h1 & 288 & 19 & $1.29 *$ & 9.5 & 1.00 & 6.0 \\
\hline P63213 & Gng2 & 79 & 6 & $1.29 *$ & 9.6 & $1.15^{*}$ & 1.8 \\
\hline Q02248 & Ctnnb1 & 63 & 3 & $1.28 *$ & 5.7 & 1.06 & 5.0 \\
\hline P19783 & Cox4i1 & 25 & 2 & $1.27 *$ & 1.9 & $1.31 *$ & 8.6 \\
\hline 008795 & Prkcsh & 24 & 4 & $1.26 *$ & 9.5 & $1.26 *$ & 8.0 \\
\hline Q9CQH7 & Btf3/4 & 59 & 2 & $1.26 *$ & 0.8 & $1.40 *$ & 5.1 \\
\hline Q61735 & $C d 47$ & 41 & 2 & $1.26 *$ & 3.1 & 1.04 & 3.4 \\
\hline 088737 & $B s n$ & 104 & 7 & $1.26 *$ & 3.1 & 1.10 & 24.3 \\
\hline Q6PCP5 & Mff & 57 & 4 & $1.25 *$ & 1.3 & 1.14 & 9.7 \\
\hline Q8BMG7 & Rab3gap2 & 41 & 2 & $1.25^{*}$ & 6.2 & 0.92 & 9.1 \\
\hline P23818 & Gria1 & 89 & 3 & $1.25 *$ & 6.6 & 1.24 & 25.8 \\
\hline P48428 & Tbca & 27 & 2 & $1.24 *$ & 2.9 & 1.20 & 9.7 \\
\hline Q9Z1G4 & Atp6v0a1 & 46 & 3 & $1.23 *$ & 8.2 & 0.98 & 5.4 \\
\hline P60879 & Snap25 & 80 & 9 & $1.23 *$ & 6.6 & 1.10 & 4.9 \\
\hline Q9QXS1 & Plec & 138 & 8 & $1.23 *$ & 3.1 & 1.05 & 9.6 \\
\hline Q9R0K7 & Atp2b2 & 79 & 4 & $1.23 *$ & 8.0 & 0.92 & 8.8 \\
\hline Q9QZM0 & Ubqln2 & 141 & 6 & $1.22 *$ & 3.3 & $1.20 *$ & 2.4 \\
\hline Q03958 & Pfdn6 & 33 & 2 & $1.22 *$ & 1.9 & $1.22 *$ & 9.0 \\
\hline P13634 & Ca1 & 144 & 5 & $1.21 *$ & 7.9 & 1.24 & 20.1 \\
\hline 088952 & Lin7c & 39 & 2 & $1.21^{*}$ & 2.3 & $1.22 *$ & 4.8 \\
\hline 055143 & Atp2a2 & 123 & 9 & $1.21^{*}$ & 7.8 & 0.88 & 8.4 \\
\hline Q9D6J6 & Ndufv2 & 109 & 6 & $1.18^{*}$ & 2.4 & $1.18^{*}$ & 7.1 \\
\hline P10852 & Slc3a2 & 78 & 5 & $1.18^{*}$ & 3.3 & $1.30 *$ & 1.8 \\
\hline Q91VM5 & $R b m x / 1$ & 93 & 7 & $1.18^{*}$ & 3.4 & $1.15^{*}$ & 2.4 \\
\hline
\end{tabular}

Page 1 from 2 
Tab. S5 Hippocampus: Proteins differently expressed in "MDMA low sociability" vs. "MDMA high sociability" group

\begin{tabular}{|c|c|c|c|c|c|c|c|}
\hline \multirow[b]{2}{*}{$\begin{array}{l}\text { UniProt } \\
\text { Accession }\end{array}$} & \multirow[b]{2}{*}{ Gene name } & \multirow[b]{2}{*}{$\begin{array}{c}\text { Mascot } \\
\text { Score }\end{array}$} & \multirow[b]{2}{*}{$\begin{array}{c}\text { \# PSMs } \\
\text { detected }\end{array}$} & \multicolumn{2}{|c|}{ MDMA low sociability } & \multicolumn{2}{|l|}{ Saline } \\
\hline & & & & $\begin{array}{l}\text { Ratio to "MDMA high } \\
\text { sociability" group }\end{array}$ & $\begin{array}{c}\text { Variability, } \\
{[\%]}\end{array}$ & $\begin{array}{l}\text { Ratio to "MDMA high } \\
\text { sociability" group }\end{array}$ & $\begin{array}{c}\text { Variability, } \\
{[\%]}\end{array}$ \\
\hline P10853 & Hist1h2bf & 93 & 7 & $1.17^{*}$ & 6.7 & $1.38 *$ & 9.4 \\
\hline Q99020 & Hnrnpab & 59 & 5 & $1.16^{*}$ & 2.7 & $1.19 *$ & 0.5 \\
\hline Q99PJ0 & Ntm & 49 & 2 & $1.15^{*}$ & 3.3 & $1.07 *$ & 0.3 \\
\hline Q9CXZ1 & Ndufs4 & 59 & 4 & $1.15^{*}$ & 3.4 & $1.25^{*}$ & 5.8 \\
\hline Q91VI7 & $R n h 1$ & 112 & 4 & $0.87 *$ & 0.7 & 0.89* & 2.0 \\
\hline P47708 & Rph3a & 104 & 4 & $0.87 *$ & 1.1 & $0.84 *$ & 3.4 \\
\hline Q9D0K2 & Oxct1 & 166 & 19 & $0.81 *$ & 7.6 & 0.95 & 5.9 \\
\hline P28652 & Camk2b & 69 & 5 & $0.80 *$ & 7.4 & $0.77 *$ & 8.0 \\
\hline P45376 & $A k r 1 b 1$ & 66 & 2 & $0.79 *$ & 1.1 & 1.01 & 24.8 \\
\hline Q60931 & Vdac3 & 71 & 5 & $0.79 *$ & 2.2 & $0.92 *$ & 2.5 \\
\hline Q8BGH2 & Samm50 & 33 & 2 & $0.79 *$ & 10.2 & $0.90 *$ & 3.0 \\
\hline Q9R0Q3 & Tmed2 & 91 & 4 & $0.78^{*}$ & 10.1 & $0.84 *$ & 6.6 \\
\hline Q8BIZ1 & Anks1b & 85 & 7 & $0.77 *$ & 7.2 & $0.85 *$ & 1.5 \\
\hline Q9ESN6 & Trim2 & 96 & 4 & $0.77 *$ & 14.4 & $0.86^{*}$ & 1.1 \\
\hline P63328 & Рpp3ca & 230 & 12 & $0.77 *$ & 15.4 & 0.85 & 16.2 \\
\hline P61161 & Actr2 & 37 & 2 & $0.76 *$ & 6.7 & $0.82 *$ & 6.0 \\
\hline P26040 & Ezr & 135 & 5 & $0.76^{*}$ & 8.3 & 0.79 & 14.8 \\
\hline Q91Z61 & Diras1 & 55 & 3 & $0.76 *$ & 14.3 & 0.87 & 13.3 \\
\hline Q60737 & Csnk2a1 & 50 & 3 & $0.74 *$ & 5.1 & 0.84 & 12.9 \\
\hline Q9Z1B3 & Plcb1 & 178 & 9 & $0.73 *$ & 14.6 & $0.81 *$ & 3.1 \\
\hline 054983 & Crym & 149 & 8 & $0.72 *$ & 9.0 & $0.82 *$ & 6.5 \\
\hline F6SEU4 & Syngap1 & 113 & 6 & $0.72 *$ & 7.4 & $0.72 *$ & 3.2 \\
\hline Q99KI0 & Aco 2 & 257 & 14 & $0.72 *$ & 10.8 & 0.82 & 11.8 \\
\hline P62192 & Psmc1 & 37 & 2 & $0.71 *$ & 19.0 & 1.04 & 4.7 \\
\hline Q64332 & Syn2 & 220 & 11 & $0.68^{*}$ & 4.6 & 0.88 & 12.9 \\
\hline P61759 & Vbp1 & 27 & 2 & $0.53 *$ & 19.8 & 0.96 & 18.5 \\
\hline P63242 & Eif5a & 85 & 3 & $0.47 *$ & 56.2 & 1.02 & 8.1 \\
\hline
\end{tabular}

Data presented as relative proteins abundances.

Significantly different values are marked with * (confidence level 0.05). 
Tab. S6 Amygdala: Proteins differently expressed in "MDMA low sociability" vs. "MDMA high sociability" group.

\begin{tabular}{|c|c|c|c|c|c|c|c|}
\hline \multirow{2}{*}{$\begin{array}{l}\text { UniProt } \\
\text { Accession }\end{array}$} & \multirow[b]{2}{*}{ Gene name } & \multirow{2}{*}{$\begin{array}{l}\text { Mascot } \\
\text { Score }\end{array}$} & \multirow{2}{*}{$\begin{array}{l}\text { \# PSMs } \\
\text { detected }\end{array}$} & \multicolumn{2}{|c|}{ MDMA low sociability } & \multicolumn{2}{|l|}{ Saline } \\
\hline & & & & $\begin{array}{l}\text { Ratio to "MDMA high } \\
\text { sociability" group }\end{array}$ & $\begin{array}{c}\text { Variability, } \\
{[\%]}\end{array}$ & $\begin{array}{l}\text { Ratio to "MDMA high } \\
\text { sociability" group }\end{array}$ & $\begin{array}{c}\text { Variability, } \\
{[\%]}\end{array}$ \\
\hline P11627 & L1cam & 35 & 3 & $1.88^{*}$ & 14.8 & 1.19 & 15.0 \\
\hline Q8BIZ1 & Anks1b & 65 & 7 & 1.63* & 6.9 & 1.23 & 15.7 \\
\hline Q9Z2Y3 & Homer1 & 40 & 4 & $1.55^{*}$ & 1.1 & 1.29 & 5.9 \\
\hline Q99JB2 & Stom/2 & 23 & 2 & 1.53* & 10.3 & 1.00 & 30.1 \\
\hline F6SEU4 & Syngap1 & 52 & 5 & $1.46 *$ & 5.0 & 1.14 & 5.1 \\
\hline 054983 & Crym & 102 & 11 & $1.42 *$ & 10.5 & 1.00 & 20.3 \\
\hline P14206 & Rpsa & 27 & 3 & $1.41 *$ & 10.4 & 1.02 & 52.0 \\
\hline Q7TPR4 & Actn1 & 140 & 20 & $1.36 *$ & 7.6 & 1.16 & 18.0 \\
\hline P63216 & Gng3 & 33 & 3 & $1.34 *$ & 8.3 & 1.16 & 1.4 \\
\hline P34914 & Ephx2 & 28 & 2 & $1.33 *$ & 9.6 & 1.15 & 26.3 \\
\hline P33173 & Kif1a & 92 & 7 & $1.32 *$ & 12.3 & 1.19 & 3.6 \\
\hline Q8CCT4 & Tceal5 & 80 & 8 & $1.30 *$ & 5.1 & 0.96 & 12.7 \\
\hline P31324 & Prkar2b & 107 & 14 & $1.30 *$ & 8.8 & 1.08 & 5.7 \\
\hline Q9R257 & Hebp1 & 44 & 3 & $1.29 *$ & 10.5 & 1.12 & 21.6 \\
\hline P23818 & Gria1 & 42 & 6 & $1.27 *$ & 5.0 & 1.08 & 3.9 \\
\hline Q9Z2W9 & Gria3 & 70 & 5 & $1.27 *$ & 0.6 & 1.18 & 3.5 \\
\hline Q9ZOH4 & Celf2 & 58 & 3 & $1.25 *$ & 0.6 & 1.07 & 2.0 \\
\hline Q8BGZ1 & Hpcal4 & 161 & 13 & $1.24 *$ & 6.9 & 1.16 & 7.2 \\
\hline Q9D8W7 & Ociad2 & 35 & 3 & $1.23 *$ & 9.5 & 1.18 & 4.1 \\
\hline P58774 & Tpm2 & 145 & 13 & $1.21 *$ & 7.6 & 1.11 & 4.2 \\
\hline P97315 & Csrp1 & 59 & 4 & $0.84 *$ & 4.6 & 0.39 & 34.2 \\
\hline P13707 & Gpd1 & 89 & 7 & $0.80 *$ & 6.0 & 0.96 & 6.9 \\
\hline Q61292 & Lamb2 & 40 & 3 & $0.80 *$ & 6.6 & 0.89 & 4.0 \\
\hline Q9D154 & Serpinb1a & 81 & 8 & 0.79* & 1.8 & 1.06 & 8.6 \\
\hline P16330 & Cnp & 342 & 57 & $0.78^{*}$ & 8.5 & 1.02 & 10.9 \\
\hline Q97306 & Slc22a4 & 47 & 3 & $0.77 *$ & 4.5 & 1.00 & 0.7 \\
\hline Q9CQ54 & Ndufc2 & 40 & 4 & $0.76 *$ & 12.5 & 0.94 & 14.2 \\
\hline Q9CPX6 & $\operatorname{Atg} 3$ & 38 & 3 & $0.75^{*}$ & 6.7 & 0.72 & 21.1 \\
\hline Q8BGN3 & Enpp6 & 62 & 7 & $0.74 *$ & 13.6 & 1.03 & 7.2 \\
\hline P03995 & Gfap & 651 & 63 & $0.74 *$ & 12.5 & 0.79 & 15.1 \\
\hline P62301 & Rps13 & 40 & 4 & $0.70 *$ & 3.8 & 0.78 & 32.6 \\
\hline Q61885 & Mog & 70 & 7 & $0.69 *$ & 7.5 & 1.03 & 16.1 \\
\hline Q80UW2 & Fbxo2 & 34 & 2 & $0.66 *$ & 22.6 & 0.85 & 11.9 \\
\hline Q9D2P8 & Mobp & 64 & 7 & $0.64 *$ & 16.3 & 1.14 & 4.4 \\
\hline
\end{tabular}

Data presented as relative proteins abundances

Significantly different values are marked with * (confidence level 0.05). 